\title{
Ranavirus Replication: Molecular, Cellular, and Immunological Events
}

\author{
James K. Jancovich, Qiwei Qin, Qi-Ya Zhang, and V. Gregory Chinchar
}

\section{Introduction}

Since their discovery nearly 50 years ago, our understanding of ranavirus biology has developed in two distinct stages. The first, driven by the work of Allan Granoff, his collaborators, and other investigators in Europe and the USA, took place between 1965 and 1985. During this initial period, the principal events in ranavirus replication in cell culture were elucidated through the study of Frog virus 3 (FV3), the type species of the genus Ranavirus (family Iridoviridae). The second wave of ranavirus research began in the 1990s and continues to the present day. These studies, conducted in the USA and, increasingly, in Asia and Europe, are focused on ranavirus genes and genomes and have employed a variety of contemporary molecular approaches to ascertain the role of specific genes in viral replication. Moreover, current work has expanded beyond FV3 and has utilized additional ranavirus species as well as iridoviruses from other genera, especially the genus Megalocytivirus. Recent studies have identified viral genes that not only play direct structural and enzymatic roles in ranavirus replication, but also genes that likely enhance virus replication in

\footnotetext{
J.K. Jancovich

Department of Biological Sciences, California State University, San Marcos, CA 92096, USA

Q. Qin

Key Laboratory of Tropical Marine Bio-Resources and Ecology, South China Sea Institute of Oceanology, Chinese Academy of Sciences, Guangzhou, China

Q.-Y. Zhang

State Key Laboratory of Freshwater Ecology and Biotechnology, Institute of Hydrobiology, Chinese Academy of Sciences, Wuhan, Hubei, China

V.G. Chinchar $(\triangle)$

Department of Microbiology, University of Mississippi Medical Center, Jackson, MS 39216, USA

e-mail: vchinchar@umc.edu
} 
particular cellular and host environments, evade antiviral immune responses, and contribute to virulence. Ongoing studies involving the "knock out" of viral genes, "knock down" of gene function, and analysis of recombinant ranavirus proteins are providing a more complete understanding of viral gene function. Moreover, by identifying viral genes that play critical roles in virulence, these studies will provide a better understanding of protective innate and acquired immune responses in lower vertebrates and facilitate the development of effective anti-ranavirus vaccines. In addition to the biochemical and genetic studies that are the focus of this chapter, there has been an explosion of information describing the adverse impact that ranaviruses, and other vertebrate iridoviruses, have on wild and cultured ectothermic vertebrates (Duffus et al. 2015; Brunner et al. 2015). To provide a basis for understanding the molecular mechanisms of ranaviral disease, we describe below the salient events in ranavirus replication and the role of specific viral genes in this process. Although focused mainly on viral replication strategies as well as classical and contemporary methods for determining viral gene function, we also touch briefly on viral taxonomy and antiviral immune responses, two topics covered at length in other chapters within this book (Jancovich et al. 2015; Grayfer et al. 2015).

\section{Ranavirus Taxonomy and Genomes}

The genus Ranavirus is one of five genera within the family Iridoviridae (Table 1). The genera that comprise the family include two that infect only invertebrates, Iridovirus and Chloriridovirus, and three that target cold-blooded vertebrates, Ranavirus, Megalocytivirus, and Lymphocystivirus (Jancovich et al. 2012). Whereas megalocyti- and lymphocystiviruses infect only fish, ranaviruses, despite their eponymous designation, target fish, amphibians, and reptiles. Moreover, indicative of their broad host range, some ranaviruses infect hosts from different vertebrate classes. For example, Bohle iridovirus (BIV) is capable of infecting both amphibians and fish (Moody and Owens 1994). Viral promiscuity is especially evident in vitro where ranaviruses infect cells from multiple vertebrate species, including mammals. Iridovirids, a generic designation for all members of the family, possess an icosahedral capsid that encloses a dsDNA genome. A summary of iridovirid genomic features, including abbreviated species and isolate designations, is found in Table 1. As shown therein, genomes vary in size depending upon the specific virus, and contain between 92 and 211 putative open reading frames (ORFs) (Jancovich et al. 2012). Phylogenetic analysis of a set of 26 genes conserved among all members of the family support the division of the family into four distinct groups: Ranavirus, Megalocytivirus, Lymphocystivirus, and Iridovirus/Chloriridovirus (Eaton et al. 2007). Although not distinguished phylogenetically, iridoviruses and chloriridoviruses display marked differences in the percentage of guanine and cytosine $(\mathrm{G}+\mathrm{C})$ residues, virion size, and host range. Whether these features provide sufficient grounds for the current division into two genera remain to be determined.

Early studies on ranavirus genomes focused on FV3 and showed that it possessed a linear, double-stranded DNA genome that was circularly permutated and termi- 
Table 1 Iridovirus taxonomy: viral genera and species

\begin{tabular}{|c|c|c|c|c|c|}
\hline Genus & Species $^{\mathrm{a}}$ & Size (bp) & No. ORFs & $\% \mathrm{G}+\mathrm{C}$ & GenBank accession number \\
\hline \multirow[t]{2}{*}{ Iridovirus } & IIV-9 & 206,791 & 191 & 31 & GQ918152 \\
\hline & $I I V-6$ & 212,482 & 211 & 29 & AF303741 \\
\hline Chloriridovirus & $I I V-3$ & 191,132 & 126 & 48 & DQ643392 \\
\hline \multirow[t]{2}{*}{ Lymphocystivirus } & $L C D V-1$ & 102,653 & 108 & 29 & L63545 \\
\hline & LCDV-C & 186,250 & 178 & 27 & AY380826 \\
\hline \multirow[t]{11}{*}{ Ranavirus } & $A T V$ & 106,332 & 92 & 54 & AY150217 \\
\hline & FV3 & 105,903 & 97 & 55 & AY548484 \\
\hline & $E H N V$ & 127,011 & 100 & 54 & FJ433873 \\
\hline & ADRV & 106,734 & 101 & 55 & KC865735 \\
\hline & STIV & 105,890 & 103 & 55 & EU627010 \\
\hline & CMTV & 106,878 & 104 & 55 & JQ231222 \\
\hline & TFV & 105,057 & 105 & 55 & AF389451 \\
\hline & RGV & 105,791 & 106 & 55 & JQ654586 \\
\hline & ESV & 127,732 & 136 & 54 & JQ724856 \\
\hline & SGIV & 140,131 & 139 & 49 & AY521625 \\
\hline & GIV & 139,793 & 139 & 49 & AY666015 \\
\hline \multirow[t]{6}{*}{ Megalocytivirus } & ISKNV & 111,362 & 117 & 55 & AF371960 \\
\hline & RBIV & 112,080 & 116 & 53 & AY532606 \\
\hline & RSIV & 112,414 & 93 & 53 & BD143114 \\
\hline & OSGIV & 112,636 & 116 & 54 & AY894343 \\
\hline & TRBIV & 110,104 & 115 & 55 & GQ273492 \\
\hline & LYCIV & 111,760 & ND & ND & AY779031 \\
\hline
\end{tabular}

aIIV-9 invertebrate iridovirus type 9, IIV-6 invertebrate iridovirus type 6 (Chilo iridovirus), IIV-3 invertebrate iridovirus type 3, LCDV-1 lymphocystis disease virus 1, LCDV-C lymphocystis disease virus - China, TFV tiger frog virus, ATV Ambystoma tigrinum virus, FV3 Frog virus 3, RGV Rana grylio virus, $C M T V$ common midwife toad virus, $S T I V$ soft-shelled turtle iridovirus, ADRV Andrias davidianus ranavirus, EHNV epizootic haematopoietic necrosis virus, ESV European sheatfish virus, SGIV Singapore grouper iridovirus, GIV grouper iridovirus, ISKNV infectious spleen and kidney necrosis virus, RBIV rock bream iridovirus, RSIV red seabream iridovirus, OSGIV orange spotted grouper iridovirus, TRBIV turbot reddish body iridovirus, $L Y C I V$ large yellow croaker iridovirus. Viral names in bold italic type indicate species recognized by the International Committee on Taxonomy of Viruses; those in standard type are either tentative species or isolates of recognized species, $N D$ not determined

nally redundant, a characteristic of all viral genomes within the family Iridoviridae (Goorha and Murti 1982). In addition, the FV3 genome, as well as all other vertebrate iridoviruses with the exception of Singapore grouper iridovirus (SGIV), were shown to be highly methylated with each cytosine within every $\mathrm{CpG}$ dinucleotide methylated (Willis and Granoff 1980). While these early studies gave insight into the overall structure of ranavirus genomes, little was known about the genetic composition, coding capacity, and variations among ranavirus genomes.

As the second wave of ranavirus research built momentum, our understanding of ranavirus genomes quickly expanded. Beginning in 1997 with the sequencing of the genome for lymphocystis disease virus (Tidona and Darai 1997), complete genomic sequences were determined for a number of iridovirids, including multiple ranavirus species and isolates infecting a variety of hosts (Table 1). The availability of complete 
genomic sequence information permitted analysis of overall genomic organization, protein sequence variation, and polymorphic regions among ranaviruses.

Ranavirus genomes range in size from 105 to $140 \mathrm{kbp}$, display a $\mathrm{G}+\mathrm{C}$ content between 49 and $55 \%$, and are predicted to encode 92-139 viral proteins (Table 1). Currently, four unique genomic organizations, divisible into two groups, have been identified by dot plot and phylogenetic analyses of completely sequenced ranavirus genomes (Chen et al. 2013). Grouper iridovirus (GIV)-like ranaviruses (GIV and SGIV) comprise one group, while amphibian-like ranaviruses (ALRV) make up the second. GIV-like viruses display only short segments of genomic colinearity when compared to other members of the genus, whereas members of the ALRV group (i.e., ATV-, CMTV-, and FV3-like ranaviruses) share longer regions of colinearity (Jancovich et al. 2010; Chen et al. 2013; Mavian et al. 2012). However, among the three ALRV subgroups, inversion, deletions, and additions, have occurred that distinguish one from the other (Fig. 1).

Ranavirus genomes encode between 92 and 139 putative gene products that have been identified by detection of ORFs longer than 50 amino acids, SDS-
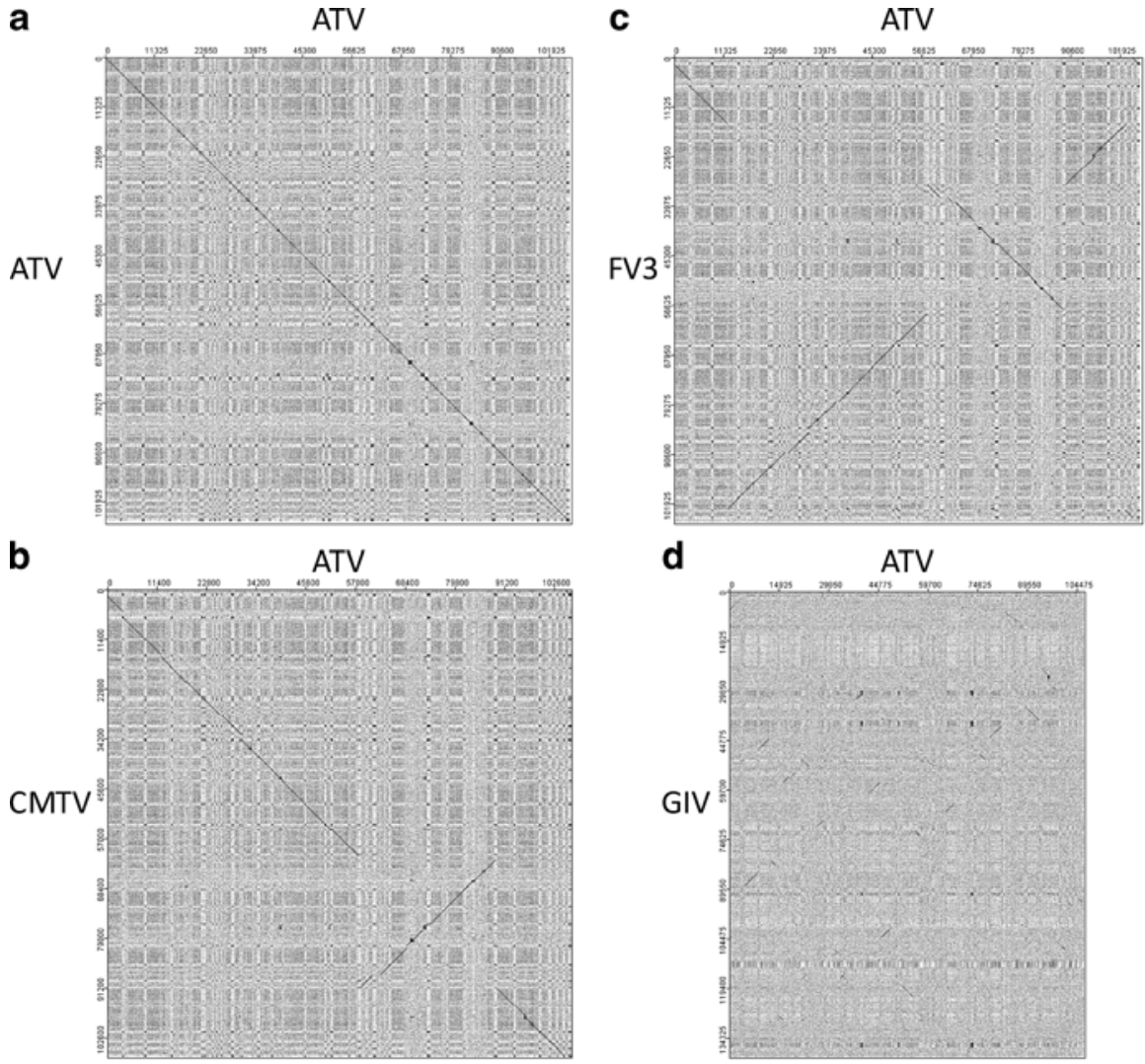

Fig. 1 Ranavirus genomic organization: Dotplot analysis of the genomic organization of representative members of the genus Ranavirus. The genomic sequence of ATV was compared to: (a) ATV; (b) CMTV; (c) FV3; (d) GIV. Dot plots were generated using JDotter (Brodie et al., 2004). Lines on the plot indicate regions of sequence similarity/colinearity 
polyacrylamide gel analysis of purified virions and virus-infected cells, microarray analysis of viral transcripts, and proteomic analysis of virions (Eaton et al. 2007; Majji et al. 2009; Song et al. 2006). The functions of about a third of these genes have been inferred by similarity to other known proteins or genes. Although the roles of the remaining genes are unknown, most are homologous to genes within the family Iridoviridae indicating that they play important roles in viral biogenesis. All ranaviruses contain 26 core iridovirus genes as well as an additional 72 genes that are common to all members of the genus (Eaton et al. 2007). Since the latter are found only among ranaviruses, we hypothesize that by identifying their various roles in replication we may be able to identify genes that function in unique host environments and cause disease in a wide variety of hosts.

In addition to coding regions, ranavirus genomes contain palindromes, microsatellites, repeat regions, and areas of inter- and intragenic variation (Eaton et al. 2010; Jancovich et al. 2003; Lei et al. 2012b; Mavian et al. 2012; Morrison et al. 2014; Tan et al. 2004). Repeat and variable regions may serve as sites that facilitate recombination or regulate gene expression, and palindromic sequences at the $3^{\prime}$ end of viral messages may act as transcriptional termination signals. In addition, comparisons of closely related FV3-like viruses that vary in virulence suggest that intragenic differences, as well as variation within repeated sequences, may influence viral pathogenesis (Morrison et al. 2014).

There is growing evidence that ranaviruses encode microRNAs (miRNAs) that regulate host and viral gene expression and play a role in the evasion of host antiviral immunity. For example, 11 of the 16 novel SGIV-encoded miRNAs identified by Illumina/Solexa deep-sequencing were present and functional in SGIV-infected grouper cells when examined by stem-loop quantitative RT-PCR and luciferase reporter assays (Yan et al. 2011). One miRNA, SGIV miR-homoHSV attenuated SGIV-induced apoptosis thereby enhancing virus replication (Guo et al. 2013). Taken together, these data suggest that sequence variations among ranavirus genomes may significantly influence ranavirus host range and pathogenesis. To that end, our understanding of ranavirus genomics will expand as additional ranavirus genomes are sequenced.

\section{Ranavirus Replication Strategy}

In this section, we discuss virus-encoded events that play direct roles in the production of infectious virus particles, and in the following sections the impact of virus infection on host cells and the interaction between the virus and host immune system. For the most part, ranavirus replication will be reviewed using FV3 as the model, but where appropriate other ranaviruses, or even viruses from other genera within the family, will be discussed. Key events in ranavirus replication are shown schematically in Fig. 2. While the events depicted in Fig. 2 are based, for the most part, on work with FV3, it appears that all vertebrate iridoviruses replicate using essentially the same general strategy. Differences among ranaviruses, megalocytiviruses, and lymphocystiviruses may reside in how they interact with their hosts at the cellular 


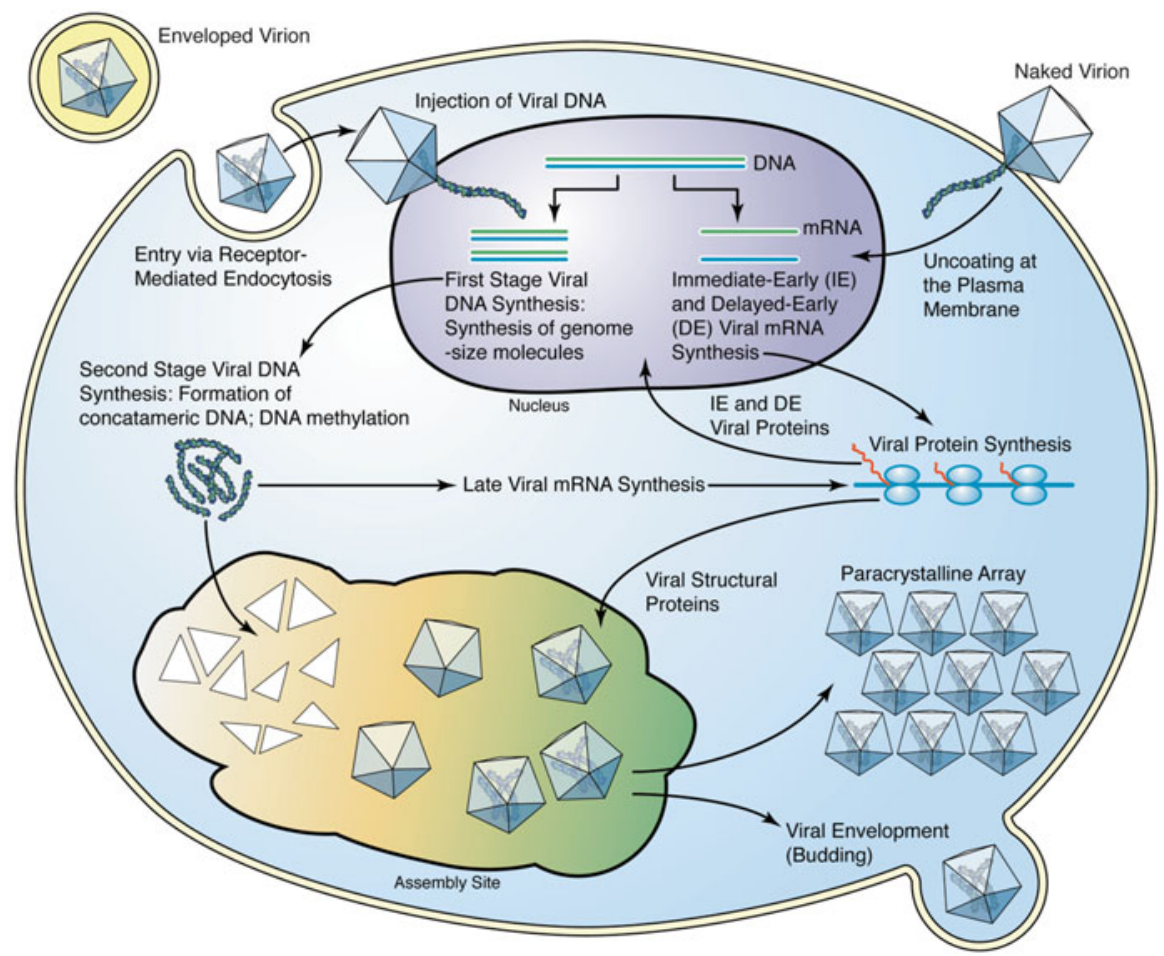

Fig. 2 Schematic diagram of ranavirus replication. Virions enter cells by one of two possible routes and initial events in virus replication (early viral transcription and the synthesis of unit length genomes) take place within the nucleus. Viral genomes are subsequently transported into the cytoplasm where they are methylated and serve as templates for concatemer formation. Viral assembly sites contain viral DNA and a number of virus-encoded proteins and serve as the loci of virion formation. Newly synthesized virions are found free within the cytoplasm or within paracrystalline arrays, and, a minority, at least in vitro, bud from the plasma membrane and in the process acquire an envelope

and immunological levels. Additional information on ranavirus replication strategies can be found in several comprehensive reviews (Chinchar et al. 2009, 2011; Williams 1996; Williams et al. 2005; Willis et al. 1985).

\subsection{Viral Entry}

Ranavirus particles are complex multilayered structures consisting, from inside out, of a core composed of the viral dsDNA genome associated with one or more virusencoded proteins, an internal lipid membrane containing several intramembrane proteins, an icosahedral capsid composed almost entirely of a $\sim 48 \mathrm{kDa}$ major capsid protein $(\mathrm{MCP})$, and (in those virions that are released by budding) a viral envelope 
derived from the aforementioned plasma membrane and containing one or more virus-encoded proteins (Darcy-Tripier et al. 1984). In appearance, ranavirus particles show marked similarity to the virions of African swine fever virus (ASFV) and members of the family Phycodnaviridae (Tulman et al. 2009; Wilson et al. 2009). In contrast to members of most other virus families whose infectious forms consist of either enveloped virions or non-enveloped viral particles, both non-enveloped and enveloped ranavirus particles are infectious. However, the infectivity of enveloped virions appears to be greater and may be a reflection of their entry via receptormediated endocytosis (Braunwald et al. 1979; Ma et al. 2014). Although ranaviruses possess broad in vitro and in vivo host ranges, the identities of the viral and cellular receptor proteins are not known. Non-enveloped virions interact with the plasma membrane and uncoating is thought to take place by release of the viral DNA core into the cytoplasm. In contrast, enveloped viruses are thought to enter cells by receptor-mediated endocytosis, followed by release of non-enveloped virions into the cytoplasm. Virions are transported to the nuclear membrane and viral DNA is subsequently injected into the nucleus (Braunwald et al. 1985; Gendrault et al. 1981). The enhanced infectivity of enveloped virions may reflect the more efficient binding of viral envelope protein(s) to the cellular receptor or more efficient uptake and release achieved by receptor-mediated endocytosis. In addition to these mechanisms, entry may also involve interaction between virions and caveolae (Guo et al. 2011b, 2012; Jia et al. 2013; Wang et al. 2014).

\subsection{Nuclear Events}

The entry of viral cores into the nucleus sets the stage for the opening acts of ranavirus replication: the synthesis of early viral transcripts and the generation of unit-length copies of the viral genome. As with other DNA viruses, such as herpesviruses, ranaviruses utilize host RNA polymerase II to transcribe viral messages (Goorha 1981). However, in contrast to herpesviruses, ranavirus transcription requires the presence of one or more virion-associated proteins and, as a result, deproteinized viral genomic DNA cannot be transcribed and is not infectious (Willis et al. 1990; Willis and Granoff 1985; Willis and Thompson 1986). The first viral transcripts synthesized are termed "immediate-early" (IE) and among their gene products are one or more proteins that are required for the synthesis of a second class of early transcripts, designated "delayed early" (DE) (Willis and Granoff 1978). As a group, IE and DE transcripts likely encode regulatory and virulence proteins as well as key catalytic proteins such as the large and small subunits of the viral homolog of RNA polymerase II (vPOL-II) and the viral DNA polymerase (Majji et al. 2009). Following microarray analysis of FV3 gene expression, 33 IE and 22 DE transcripts, corresponding to approximately half of the FV3 coding potential, were identified (Majji et al. 2009). Similar levels of IE and DE gene products were seen with other ranaviruses (Chen et al. 2006; Teng et al. 2008). Host POL-II is responsible for the transcription of IE (and perhaps DE) viral mRNAs, whereas, as described below, vPOL-II 
directs transcription of late viral messages. As with host transcripts, viral transcripts are capped and methylated, but unlike cellular messages ranavirus mRNAs lack poly[A] tails and introns.

\subsection{Cytoplasmic Events}

After its transport into the cytoplasm, viral DNA is methylated by a virus-encoded cytosine-specific DNA methyltransferase (DMTase) (Willis et al. 1984; Willis and Granoff 1980). Each cytosine within $\mathrm{CpG}$ dinucleotides is targeted leading to the methylation of 20-25\% of cytosines and resulting in the highest level of DNA methylation seen among vertebrate viruses. However, despite this extraordinary level of methylation, the precise role that methylation plays in the viral life cycle is not known. Methylation has been suggested to protect viral genomic DNA from attack by a virus-encoded restriction-modification enzyme that targets unmethylated host DNA (Kaur et al. 1995). Alternatively, methylation is thought to prevent recognition of viral genomic DNA by pattern recognition receptors such as TLR-9 and thus block activation of an immune response (Hoelzer et al. 2008; Krug et al. 2001, 2004). FV3 infection in the presence of $5^{\prime}$-azacytidine (azaC), a methylation inhibitor, does not affect viral transcription or translation, but results in modest decreases in DNA synthesis and marked reductions in viral yields (Goorha et al. 1984). In support of a protective role for DNA methylation, gradient analysis detected single-stranded DNA breaks in viral DNA synthesized in the presence of azaC. These breaks were thought to block DNA packaging and the development of infectious virions.

Within the cytoplasm, unit-length genomes serve as templates for the second stage of viral DNA synthesis which results in the formation of large concatemers containing ten or more interlaced copies of the viral genome (Goorha 1982). Using a collection of temperature-sensitive $(t s)$ mutants, two complementation groups, involving first stage and second stage DNA synthesis, have been linked to viral DNA synthesis (Chinchar and Granoff 1986; Goorha and Dixit 1984; Goorha et al. 1981). Since sequence analysis identified only a single viral DNA polymerase gene, it is likely that one complementation group encodes a viral DNA polymerase that functions in both events, whereas the second may encode a viral protein needed for the transport of viral DNA from the nucleus to the cytoplasm or some other function related to concatemer formation.

\subsection{Virus Assembly}

Virion formation takes place within morphologically distinct areas of the cytoplasm referred to as virus assembly sites or virus factories. Assembly sites are electron lucent areas of the cytoplasm that are devoid of cellular organelles (Murti et al. 1985, 1988; Zhang and Gui 2012). Unlike autophagosomes, ranavirus 

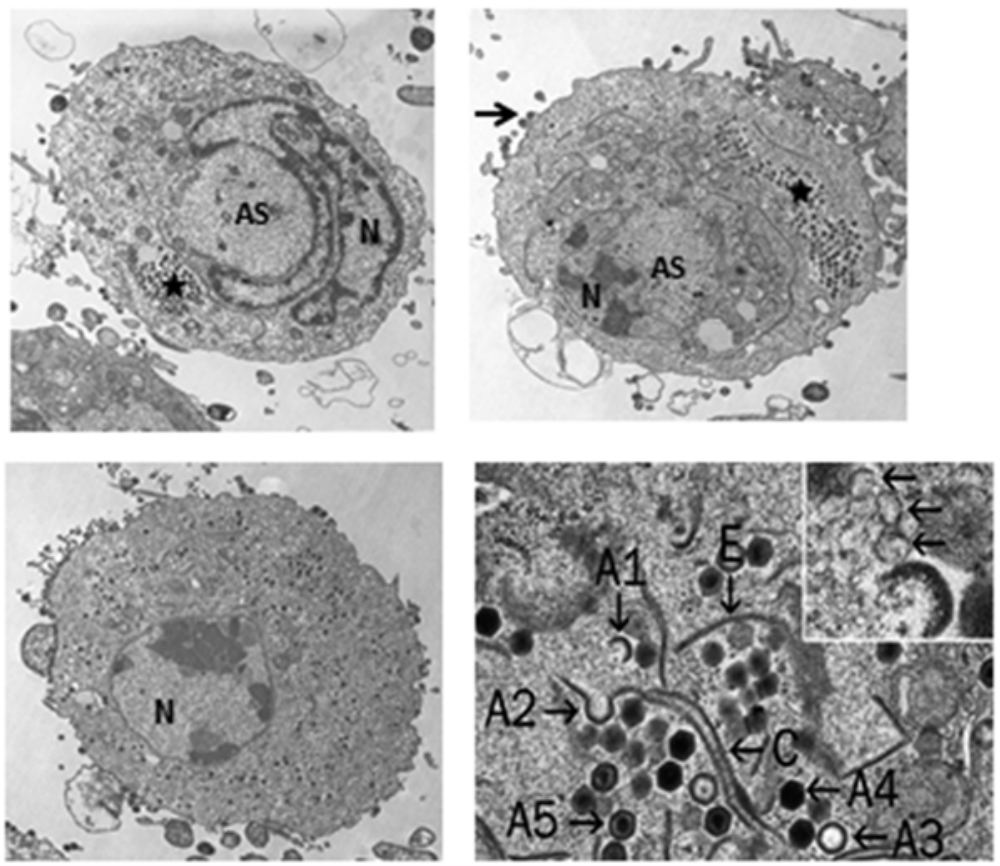

Fig. 3 Transmission electron micrographs of FV3-infected FHM cells. Upper left and right panels show typical virus-infected cells with nuclei $(\mathrm{N})$ showing evidence of chromatin condensation, well-defined viral assembly sites (AS); intracytoplasmic paracrystalline arrays (asterisk), and virions budding from the plasma membrane (arrow). Lower left panel shows a virus-infected cell in which virions are scattered throughout the cytoplasm. Lower right panel is an enlargement of a viral assembly site showing virions in various stages of assembly. Full (A4 and A5) and empty (A3) viral particles are shown as well as two possible intermediates (A1 and A2) and two aberrant forms $(\mathrm{C}$ and $\mathrm{E})$. The inset indicates membranes (arrows), possible originating from the ER, that play a role in virion morphogenesis

assembly sites are not enclosed within membranes, but are encased by intermediate filaments and surrounded by mitochondria and ribosomes (Fig. 3). Both early and late viral proteins are associated with assembly sites as well as presumably concatemeric viral DNA. Viral assembly sites were detected in the presence of an antisense morpholino oligonucleotide (asMO) that blocked late gene expression (Sample 2010; Sample et al. 2007). These results suggest that late viral protein expression is not required for assembly site development and strengthen an earlier study suggesting that early proteins are sufficient for assembly site formation (Chinchar et al. 1984; Sample 2010).

The specific steps required for the formation of infectious virus particles are still poorly understood. Genetic analysis of $t s$ mutants identified 12 complementation groups that synthesized ostensibly all viral proteins and viral DNA yet were unable to generate infectious particles (Chinchar and Granoff 1986). Transmission electron microscopic (TEM) analysis of these complementation groups identified several ts 
mutants in which virion structures did not form, whereas in others apparently complete, but noninfectious, particles were present (Purifoy et al. 1973; Sample 2010). Clearly multiple structural and catalytic proteins must be involved in the formation of infectious particles. By analogy to ASFV (Rouiller et al. 1998; Tulman et al. 2009), virion assembly may involve initial binding of a myristoylated viral protein (e.g., FV3 ORF53R) to fragments of the endoplasmic reticulum, followed by binding of the MCP on its opposite face (Whitley et al. 2010). Continued addition of $53 \mathrm{R}$ and $\mathrm{MCP}$ to membrane fragments is thought to result in the formation of crescent-shaped structures that eventually associate with viral DNA to form the virion. Consistent with this model, intermediates along the pathway to virion formation can be detected by transmission electron microscopy (Fig. 3).

The process by which viral DNA is encapsidated has not yet been determined. Although encapsidation of a "headful" of viral DNA explains the existence of circularly permuted, terminally redundant DNA genomes (Goorha and Murti 1982), it is not known if ranavirus DNA enters through a unique virion portal as seen with some dsDNA viruses or by engulfment of viral DNA by the enlarging icosahedron (Cardone et al. 2007; Chang et al. 2007). Moreover, although concatemeric DNA is thought to serve as the source of the DNA that is ultimately packaged into virions, how complete copies of the viral genome are resolved from concatemeric DNA is not known. Complete viral particles are present within viral assembly sites, the cytoplasm, paracrystalline arrays, and in association with the plasma membrane (Fig. 3). In cultured cells, most virions remain cell-associated and are released as naked particles following cell lysis. However, a variable number of particles bud from the plasma membrane and in the process acquire an envelope. The factors that determine whether a given particle remains cell-associated or enveloped are not known. Freeze-fracture electron microscopy indicates that mature FV3 particles display a Russian doll-like structure with a knobby, spherical core composed of viral DNA and associated proteins enclosed within a capsid composed primarily of a 48 kDa MCP (Darcy-Tripier et al. 1984; Devauchelle et al. 1985). Electron microscopy of Chilo iridescent virus (genus Iridovirus) has identified at least three minor proteins (designated finger, zip, and anchor) associated with the virion, but has not linked them with specific viral ORFs (Yan et al. 2009). In addition to the major and minor structural proteins, it is thought that other viral proteins, e.g., proteins responsible for translational shut-off and the transactivation of IE transcription, are also associated with mature virions. As described in Grayfer et al. (2015), these latter proteins may also contribute to virulence

In contrast to early viral messages that are, at least initially, transcribed in the nucleus by host POL-II, late viral messages such as those encoding the MCP and other virion-associated proteins may be transcribed within the cytoplasm by vPOL-II, a virus-encoded RNA polymerase whose two largest subunits are homologous to the corresponding units of cellular RNA polymerase II (Tan et al. 2004; Sample et al. 2007). As discussed below, knock down studies using an asMO targeted to vPOL-II $\alpha$ resulted in a marked reduction in the synthesis of all 
late proteins. At this time, it is not known if vPOL-II $\alpha$ and vPOL-II $\beta$ function as a minimal, two-subunit RNA polymerase, or whether these two viral subunits associate with other cellular or viral proteins to form the functional enzyme. In addition to the requirement for functional vPOL-II, late transcription is also dependent upon ongoing viral DNA synthesis as $t s$ mutants defective in viral DNA synthesis or treatment of FV3-infected cells with DNA synthesis inhibitors such as phosphonoacetic acid (PAA) or cytosine arabinoside (araC) also inhibit late viral gene expression (Chinchar and Granoff 1984, 1986). In cell culture, FV3 replication takes place within a $12-24 \mathrm{~h}$ period. Early messages are detectable within the first $4 \mathrm{~h}$; late transcripts and proteins, e.g., the MCP, by $8 \mathrm{~h}$ post infection; and virus particles by $8-12 \mathrm{~h}$. However, the kinetics of viral replication are influenced by the multiplicity of infection, temperature, and metabolic state of the host cell. As stated above, although all vertebrate iridoviruses are thought to replicate using the same general strategy, differences among them likely influence how they interact with their hosts at the cellular and immunological levels and impact replication in vivo.

\section{Impact of Virus Infection on the Host Cell}

\subsection{Cell Death: Necrosis, Apoptosis, and Parapoptosis}

Ranavirus infections result in the rapid inhibition of host DNA, RNA, and protein synthesis and culminate in rapid cell death (Goorha and Granoff 1979; Raghow and Granoff 1979). Interestingly, both infectious and noninfectious virions (i.e., heat- or UV-inactivated virus) trigger the turn off of cellular transcription and translation indicating that the "shut-off protein" is virion-associated (Cordier et al. 1981; Raghow and Granoff 1979). Furthermore, virus-infected cells undergo apoptosis as indicated by chromatin condensation and the fragmentation of cellular DNA (Chinchar et al. 2003). Apoptosis appears following either productive infection or infection by inactivated virions and may result from the prior inhibition of host cell macromolecular synthesis or the activation of protein kinase $\mathrm{R}$ (PKR). Ranavirusinduced apoptosis is dependent upon caspase activation and can be prevented by caspase inhibition (Chinchar et al. 2003).

In addition to apoptotic death, SGIV, the most phylogenetically distant member of the genus Ranavirus, triggers different forms of programmed cell death depending upon the cell type. In cultured grouper cells, a natural host for SGIV, infection triggers a nonapoptotic form of programmed cell death designated parapoptosis. Parapoptosis is characterized by the appearance of cytoplasmic vacuoles, distended endoplasmic reticulum, and the absence of DNA fragmentation, apoptotic bodies, and caspase activation. In contrast, in cells cultured from a non-host fish, e.g., fathead minnow (FHM), SGIV induces the typical form of apoptosis characterized by 
caspase activation and DNA fragmentation. Furthermore, disruption of mitochondrial transmembrane potential and externalization of phosphatidylserine (PS) are not detected in grouper cells but are seen in FHM cells after SGIV infection (Huang et al. 2011a). Similar results are obtained in GIV-infected grouper kidney cells. However, whether all ranaviruses modulate the survival of host and non-host cells differently requires further study (Pham et al. 2012). In host fish, mitogen-activated protein kinase (MAPK) cascades are involved in SGIV-induced parapoptosis, including extracellular signal-regulated kinase (ERK), p38 mitogen-activated protein kinase (p38 MAPK), and c-Jun N-terminal kinase (JNK) signaling (Huang et al. 2011a, b). Moreover, transcription of grouper immune genes, such as interferon regulatory factor 1 (IRF1), interleukin-8 (IL-8), and tumor necrosis factor alpha $(\mathrm{TNF}-\alpha)$ were regulated by JNK, while only $\mathrm{TNF}-\alpha$ was regulated by $\mathrm{p} 38$ MAPK. It is proposed that the JNK pathway is important for SGIV replication and modulates the inflammatory responses during virus infection (Huang et al. 2011b). Interestingly, activation of similar genes was seen following infection of FHM cells with FV3 (Cheng et al. 2014).

\subsection{Host Shut-Off and the Selective Expression of Viral Gene Products}

Despite the rapid inhibition of host macromolecular synthesis, viral DNA replication, transcription, and translation remain unaffected and abundant levels of infectious viral particles are produced within $24 \mathrm{~h}$ or less (Willis et al. 1985). The maintenance of viral protein synthesis in the face of the marked inhibition of cellular translation is likely the result of several factors. In the first place, a viral homolog of eukaryotic translational initiation factor $2 \alpha(\mathrm{vIF} 2 \alpha)$ acts as a pseudosubstrate, binds PKR, and prevents the phosphorylation and subsequent inactivation of cellular eIF2 $\alpha$ (Jancovich and Jacobs 2011). In addition, abundant levels of highly efficient viral messages outcompete host transcripts for access to the cellular translational machinery (Chinchar and Yu 1990a, b). In contrast, it is not clear how ranaviruses selectively inhibit host transcription. Perhaps ranaviruses target host POL-II as infection progresses, and rely upon vPOL-II to synthesize viral transcripts in the cytoplasm. If this model is correct, it would be instructive to determine whether early genes continue to be synthesized at later times using vPOL-II to catalyze their synthesis. As with transcription and translation, host DNA synthesis is also blocked. However, inhibition of host DNA synthesis is thought to be a consequence of the earlier blocks to cellular protein and RNA synthesis. Furthermore, a virus-encoded endonuclease, perhaps part of a restriction-modification system, is thought to degrade host DNA. Not only will this negatively impact host transcription, but the resulting nucleotides may also be re-utilized for the synthesis of viral DNA (Feighny et al. 1981; Kaur et al. 1995). 


\section{Interplay Between Host and Virus Determines the Outcome of Infection at the Organismal Level}

Virulence is a function of several factors but the two that are likely most important involve those that enhance virus replication and those that block host immune defenses. Large DNA viruses such as herpesviruses and poxviruses encode numerous genes that fulfill these functions and preliminary findings among ranaviruses suggest that they are no different (Eaton et al. 2007). In the case of viral genes that enhance replication, prime examples are viral homologs of the large and small subunits of ribonucleotide reductase (RR). Both Vaccinia virus (VACV) and herpes simplex virus 1 (HSV1) encode RR genes. VACV RR2 subunits form functional complexes with host RR1 and provide sufficient dNTPs for viral replication (Gammon et al. 2010). Likewise HSV and pseudorabies virus-encoded RR convert ribonucleoside diphosphates into the corresponding deoxyribonucleotides and play key roles in viral DNA synthesis by maintaining dNTP pool sizes (Conner et al. 1994a, b; Daikoku et al. 1991). Consistent with this key role in viral biogenesis, mutants defective in RR expression are avirulent in vivo (de Wind et al. 1993). However, in addition to their role in dNTP synthesis, HSV-1 and HSV-2 RR1 subunits also protect cells from apoptosis (Chabaud et al. 2007; Langelier et al. 2002). In contrast to the $\alpha$ - and $\beta$-herpesviruses, the RR1 subunit of murine cytomegalovirus is catalytically inactive and does not play a role in increasing dNTP pool sizes. Rather it has evolved a new function in which it inhibits RIP1, a cellular adaptor protein, and blocks signaling pathways involved in innate immunity and inflammation (Lembo and Brune 2009). Other viral genes that contribute to enhanced replication encode viral homologs of dUTPase and thymidine kinase (Eaton et al. 2007). It is likely that the RR1, RR2, dUTPase, and thymidine kinase homologs encoded by FV3 and other ranaviruses play similar critical roles in viral replication.

In addition to genes that enhance viral replication, viruses also encode genes that inhibit or counteract host immune responses. Poxviruses contain over two dozen genes whose sole function is to block one or more aspects of innate or acquired immunity (Seet et al. 2003), and it has been estimated the perhaps half of the genes encoded by human cytomegalovirus may be involved in immune evasion (Eberhardt et al. 2013). For example, poxviruses encode decoy receptors for IFN $\alpha / \beta$, IFN- $\gamma$, IL-1 $\beta$, IL-18, various chemokines, and complement that bind their cognate targets and downregulate their effector functions (Johnston et al. 2005; Johnston and McFadden 2003, 2004; Seet et al. 2003). In addition, virus-encoded miRNAs may also play critical roles in blocking host responses or controlling viral replication (Babu et al. 2014; Hook et al. 2014; Pavelin et al. 2013).

Sequence analysis of the genome of FV3 and other vertebrate iridoviruses has identified several putative genes that may play roles in blunting host immunity. These putative immune evasion proteins include the aforementioned viral homolog of eIF-2 $\alpha$ (vIF-2 $\alpha$ ), a viral homolog of RNAse III, a virus-encoded CARD (caspase activation and recruitment domain)-containing protein, a viral homolog of steroid 
dehydrogenase ( $\beta$-HSD), a viral Bcl-2 homolog, and one or more TNFR homologs (Huang et al. 2013b; Lin et al. 2008; Tan et al. 2004). In addition to these putative immune effectors, there are other viral genes that are unique to specific viruses or genera and may represent proteins that act only within specific host species, tissues, or cells. For example, there are a dozen open reading frames that are found only among ranaviruses that might encode unique polypeptides that enhance viral replication or impair immunity within specific ectothermic hosts (Eaton et al. 2007). However, the challenge of identifying virulence proteins by similarity searches is considerable. Because the level of similarity between viral and cellular homologs, even in mammalian systems, may be low, identification of a viral protein as a potential inhibitor of a specific function is far from certain unless key sequence motifs are conserved. For a given viral protein, conclusive evidence for a specific role in virulence will require using the genetic and biochemical approaches discussed below.

\section{Antiviral Immunity}

Because host antiviral immunity is discussed in Grayfer et al. (2015), only a brief summary will be presented here. The host immune response to ranavirus infection has been productively examined using a model pairing FV3, the best characterized ranavirus at the molecular level, with Xenopus laevis, the amphibian with the most fully characterized immune system (Robert 2010). Robert and colleagues have shown that infection of immunocompetent adult frogs is usually limited to the kidney and resolves with a few weeks with minimal mortality (Gantress et al. 2003). In contrast, tadpoles, which are naturally defective in MHC I expression, and immunocompromised adult animals, are susceptible to infection and display considerable morbidity and mortality (Tweedell and Granoff 1968; Gantress et al. 2003; Robert et al. 2005). In immunodeficient or immunocompromised Xenopus, infection begins in the kidney, but becomes systemic and spreads to multiple organs including the liver, gastrointestinal tract, and skin (Gantress et al. 2003). Consistent with observations that fish could be protected from ranavirus- and megalocytivirus-induced disease by vaccination with inactivated virions or a DNA vaccine (Caipang et al. 2006a, b; Ou-yang et al. 2012), antibody responses were shown to play a protective role in FV3 infections (Maniero et al. 2006). Likewise, cell-mediated immunity was shown to play an important role in protection from FV3-induced disease (Morales and Robert 2007). Recently macrophages were shown to be susceptible to FV3 infection (Morales et al. 2010). Although macrophages likely play a critical role in immunity, their infection may have two untoward effects: eliminating their ability to process and present viral antigens and providing a source of persistently infected cells that may facilitate the maintenance of virus in a population.

Although their roles in survival have yet to be determined, it is likely that multiple cellular genes that play various roles in antiviral immunity and virus replication are induced following ranavirus infection. Consistent with this suggestion, Cheng et al. (2014) recently examined the response of FHM cells to infection with 
either wild type FV3 or a knock out mutant lacking the ranavirus vIF-2 $\alpha$ and observed the induction of multiple immune-response genes at the transcriptional level including IFN, IL-8, GILT, IRF-3. Likewise, vaccination of groupers with inactivated SGIV induced the expression of numerous immune-related genes including Mx1, ISG15, IL-8, IL-1 $\beta$, and MHC I/II indicating that the immune response is conserved among different fish species and similar to that seen in mammals (Ou-yang et al. 2012).

Recently, Grayfer et al. (2014) reported the cloning and sequencing of interferon from Xenopus laevis ( $\mathrm{Xl}$-IFN). They showed that recombinant $\mathrm{Xl}$-IFN protected A6 amphibian cells from FV3 infection and transiently protected tadpoles. As expected, FV3-infected adults synthesized $\mathrm{Xl}$-IFN sooner and in higher amounts than tadpoles. Surprisingly, despite the more robust response of adults, viral burdens were greater in adults than tadpoles, although, as reported above, their long-term survival was higher. Moreover, although $\mathrm{Xl}$-IFN markedly impaired virus replication, it did not prevent death. Control, vector-treated tadpoles survived for an average of 26 days and experienced $90 \%$ mortality by day 32 , whereas $\mathrm{r} X l$-IFN-treated animals displayed a mean time to death of 36 days, with $90 \%$ mortality seen by day 40 . These results suggest that FV3 is more pathogenic to tadpoles than formerly thought and even low viral titers could cause extensive damage to internal organs and ultimately lead to death. In support of a protective role for IFN, transfection of a vector expressing turtle IFN- $\gamma$ into cultured STA cells was shown to result in an approximately $90 \%$ reduction in viral gene expression and a tenfold reduction in the yield of Softshell turtle iridovirus (Fu et al. 2014). Based on the results shown above, host immune responses seen after ranavirus infection are broadly similar to those seen in fish following infection with other viruses (Verrier et al. 2011).

\section{Determination of Viral Gene Function}

With the broad outlines of ranavirus replication known, the current challenge lies in elucidating the function of specific viral genes as this may provide targets for effective chemotherapy or aid in vaccine development. Determination of ranavirus gene function has accelerated markedly in the last 10 years as a variety of powerful molecular approaches have been brought to bear. These contemporary approaches, as well as more classical methodologies, are discussed below.

\subsection{Biochemical and Genetic Approaches}

The earliest attempts at identifying ranavirus gene function relied upon a combination of genetic and biochemical approaches. In the latter, various inhibitors were employed to block specific aspects of viral replication. For example, cycloheximide (CHX) blocked global protein synthesis and limited viral transcription to IE 
mRNAs, whereas flurophenylalanine (FPA), phosphonoacetic acid (PAA), and cytosine arabinoside (araC) permitted the expression of only IE and DE viral gene products (Goorha and Granoff 1979; Willis et al. 1985). It is thought that FPA is incorporated into one or more viral proteins required for late gene expression (e.g., the viral homologs of the two largest subunits of RNA polymerase II) and inhibits function by altering protein conformation. PAA and araC block viral DNA synthesis, an event that is required for full late gene expression, by specifically (e.g., PAA) or nonspecifically (e.g., araC) inhibiting viral DNA polymerase activity. The requirement for ongoing DNA replication for full late gene expression may reflect either the need for an increased number of, or conformationally altered, DNA templates.

The role of host RNA polymerase II in the transcription of early, but not late, viral mRNA was demonstrated using $\alpha$-amanitin, an inhibitor of host RNA polymerase II (Goorha 1981). When $\alpha$-amanitin was added before or at the time of infection, it blocked all viral gene expression. However, when added at late times, it had no effect on viral functions suggesting that host RNA polymerase II was only required at the beginning phase of infection (Goorha 1981). The critical role of DNA methylation in viral replication was explored using the methylation inhibitor, 5 '-azacytidine (azaC). In the presence of azaC, viral RNA and protein synthesis are not compromised, and viral DNA synthesis was only modestly affected (Goorha et al. 1984). However, in the presence of azaC, newly synthesized viral DNA lacked methylated cytosine residues and experienced single-stranded breaks. As a result, viral yields were reduced by more than a 100 -fold.

Although the above studies successfully elucidated the roles of several virusencoded proteins, because the inhibitors targeted a limited number of viral gene products (e.g., viral DNA polymerase, viral DNA methyltransferase), they were able to identify the roles of only a few of the approximately 100 putative FV3 ORFs. Attempts at identifying viral genes and their functions using traditional genetic approaches focused on the generation and characterization of drug-resistant $\left(\mathrm{PAA}^{\mathrm{R}}\right.$ and $\mathrm{azaC}^{\mathrm{R}}$ ) and temperature-sensitive $(t s)$ mutants. Characterization of an azaCresistant mutant linked a $26 \mathrm{kDa}$ protein to DMTase activity (Essani et al. 1987); studies using the PAA-resistant mutant confirmed that the drug target was the viral DNA polymerase (Chinchar and Granoff 1984). Temperature-sensitive mutants identified (via complementation analysis) 19 genes essential for viral replication (Chinchar and Granoff 1986; Naegele and Granoff 1971; Purifoy et al. 1973). These included mutants defective in RNA synthesis (five complementation groups) and viral DNA synthesis (two complementation groups). Analysis of the two DNAdeficient complementation groups supported the concept of two stages of DNA synthesis, i.e., the synthesis of unit size genomes within the nucleus, and the formation of large concatemers in the cytoplasm (Goorha and Dixit 1984; Goorha et al. 1981). The presence of at least five complementation groups displaying defects in late viral gene expression likely reflect mutations targeting the large and small subunits of viral RNA polymerase as well as other gene products required for late mRNA synthesis, e.g., transcription elongation factor SII. 
The majority of $t s$ mutants (12 complementation groups) synthesized both early and late viral proteins and viral DNA, but failed to form infectious particles at the nonpermissive temperature (Chinchar and Granoff 1986). This finding indicated that ranavirus particle assembly was not simply a concentration dependent event in which the MCP was the major, if not only, component. Electron microscopy showed that with some mutants outwardly mature but noninfectious virions were formed, whereas with others virion formation was aborted (Sample 2010). Given recent studies indicating that multiple proteins make up mature iridovirus virions (see above), it is likely that these defects reflect mutations in either critical structural proteins (e.g., MCP, 53R, anchor, finger, and zip proteins), putative scaffold proteins required for virus assembly, or in one or more virion-associated proteins required for the initiation of replication (e.g., the putative transactivator of IE transcription).

Attempts to map the genomic positions of $t s$ mutants have been challenging. Although the relative positions of a number of $t s$ mutants have been determined based on recombination frequencies (Chinchar and Granoff 1986), physical assignment of specific mutations to defined restriction fragments, as was done with herpesviruses and poxviruses, was unsuccessful. The inability of plasmids bearing ranavirus DNA to rescue $t s$ mutants is thought to be due to the degradation of input plasmid DNA by a virus-encoded endonuclease that targets unmethylated plasmid DNA. Fortunately, with complete sequencing of ATV, FV3 and other ranavirus genomes, alternative approaches for determining gene function have become available.

\subsection{Knock Down Strategies: Antisense Morpholino Oligonucleotides and RNA Interference}

Determination of the complete nucleotide sequence of FV3 and other ranavirus genomes has opened up the possibility of directly ascertaining gene function by targeting specific viral genes. Both knock down (KD, described here) and knock out (KO, described in the following section) have been used successfully. In the former, FV3 gene function was inhibited (i.e., knocked down) using either antisense morpholino oligonucleotides (asMOs) or small, interfering RNAs (siRNAs) (Sample et al. 2007; Whitley et al. 2010, 2011). asMOs are oligonucleotides ( 25 nucleotides in length) that are complementary to regions upstream of, or directly surrounding, the initiating AUG codon. They downregulate gene expression by blocking ribosomal movement ("scanning") and inhibiting protein synthesis (Hudziak et al. 2000; Summerton and Weller 1997; Summerton 2007). siRNAs are small ( 22 nucleotide) double-stranded molecules. Following their incorporation into an RNAinduced silencing complex, the strand complementary to the target message binds the target message leading to either RNA degradation or translational inhibition (Hannon 2002). In contrast to asMOs, siRNAs may bind within either coding or non-coding regions. Although algorithms exist to predict which sequences make effective siRNAs, they are not definitive and experimental validation of potential siRNAs must be carried out to ensure successful inhibition. 
Antisense morpholino oligonucleotides have been used successfully to target several FV3 genes, including those encoding the MCP, the $18 \mathrm{~K}$ immediate early protein, vPOL II $\alpha$, and 53R, a putative myristoylated membrane protein, as well as a SGIV-encoded histone-binding protein (Sample et al. 2007; Tran et al. 2011; Whitley et al. 2010, 2011). KD was verified by the absence or marked reduction of the target protein following SDS-PAGE or immunoblotting, and its effect on virus replication was monitored by transmission electron microscopy and determination of viral yields. KD of MCP and 53R resulted in marked reductions in the abundance of the target proteins, but had little to no effect on non-targeted proteins. Inhibiting the synthesis of MCP and 53R resulted in $\sim 90 \%$ reductions in virus yield and the appearance, respectively, of atypical elements (MCP) and granular particles (53R) within viral assembly sites. It is likely that a marked reduction in critical structural elements resulted in the accumulation of aberrant structures. In contrast to the above, KD of vPOL II $\alpha$ resulted in a global reduction in late protein synthesis and the absence of all structural elements within viral assembly sites. KD of the $18 \mathrm{~K} \mathrm{IE}$ protein only affected the target protein and had no adverse impact on virus yield. These results indicate that whereas MCP, 53R, and vPOL II $\alpha$ are essential proteins required for replication in vitro, $18 \mathrm{~K}$ is nonessential for replication in cultured FHM cells (Sample et al 2007; Whitley et al. 2010).

Attempts to extend these studies to other viral gene products were stymied by the inability to detect the loss of the targeted protein by either SDS-PAGE or immunoblotting. Nevertheless, we observed FV3 yields ranging from $8 \%$ (ORF 41R) to $43 \%$ (ORF 95R) of control following exposure to asMOs targeting ORF 2L (putative membrane protein), ORF 9L (NTPase/DEAD/H helicase), ORF 41R (an unknown protein, mol wt $129 \mathrm{kDa}$ ), ORF 32R (Neurofilament triplet H1 protein), ORF 38R (RR $\alpha)$, ORF 57R (Ser/Thr kinase), ORF 80L (Ribonuclease III-like protein), ORF 91R (46 kDa, immediate early protein), and ORF 95R (DNA repair protein, RAD2) (Whitley et al. 2011; VGC, unpublished observations). Partial yield reductions may reflect the fact that the targeted viral protein supplements an existing host function (e.g., ribonucleotide reductase) and may not be absolutely required for replication in cultured cells. Alternatively, a partial reduction may be due to incomplete KD. Moreover, the inability to confirm KD by SDS-PAGE may be due to either co-migration of the target protein with a more abundant protein of the same size (as was the case with 53R, Whitley et al. 2010) or its presence at only low levels in infected cells (Whitley et al. 2010). Although immunoblotting may be useful in identifying co-migrating or low abundance proteins, antibodies for detecting specific viral proteins are not readily available. Taken together KD studies have the potential for identifying three classes of viral proteins: (1) "essential" proteins that are absolutely required for virion production, e.g., the MCP and vPOL-II $\alpha$; (2) "efficiency" proteins that enhance virus replication in certain environments, e.g., viral homologs of ribonucleotide reductase, but that are not absolutely required for replication; and (3) "immune evasion" proteins that target innate and acquired components of the host antiviral immune response, e.g., viral homologs of eukaryotic translational initiation factor $2 \alpha(\mathrm{vIF}-2 \alpha)$ or $\beta$-hydroxysteroid dehydrogenase $(\beta-\mathrm{HSD})$. 
In addition to KD studies using asMOs, a limited number of studies have been conducted using siRNAs to silence viral gene expression (Dang et al. 2008; Kim et al. 2010; Whitley 2011; Xie et al. 2005). siRNA-mediated KD of FV3 MCP, vPOL-II $\alpha$, and the virus-encoded DNA methyltransferase markedly reduced levels of the cognate messages leading to $90 \%$ or greater reductions in virus yields, and showed little to no evidence of virion formation by transmission electron microscopy (Whitley et al. 2011; Xie et al. 2005). However, in contrast to KD mediated by asMOs, which could be detected following infection at multiplicities of infection (MOI) of 10 PFU/cell or higher, siRNA-mediated KD was only seen when MOIs of 0.01-0.1 were used. At higher inputs (i.e., MOI of 1-10), virus yields were not reduced by treatment with siRNAs. Although the reason for this inability is unclear, it is possible that ranaviruses, as do some other viruses, encode a gene product that blocks RNA interference (RNAi) perhaps by binding dsRNA and preventing its ability to form RNA silencing complexes.

Collectively, studies using siRNA and asMOs to inhibit the expression of specific viral genes have been extremely useful for elucidating viral gene function and determining whether a given gene is "essential" for replication in vitro. However, for viral genes that impact humoral and cell-mediated aspects of host immunity, siRNA and asMO approaches may not be suitable because the function of the targeted gene may only be required in vivo. For this reason, studies of putative virus-encoded immune evasion genes may be better suited for the knock out studies discussed below.

\subsection{Knock Out Mutants}

Until recently, ranavirus research has been limited by an inability to achieve recombination between an introduced plasmid and an infecting viral genome. This difficulty prevented the physical mapping of $t s$ mutants by marker rescue and the generation of recombinant viruses. Recently, methodologies utilizing efficient selection techniques capable of isolating rare recombinants have been developed. For example, recombinant SGIV, expressing enhanced green fluorescent protein (EGFP) fused to the envelope protein VP55, was constructed and used to evaluate the dynamics of viral replication (Huang et al. 2011c). Likewise, ranaviruses bearing drug resistance genes have been introduced into ATV, Rana grylio virus (RGV), and FV3 (see below). Thus, despite initial difficulties in generating recombinant ranaviruses, techniques based on the selection of fluorescent or drug-resistant viruses have emerged which allow their efficient isolation.

The first recombinant ranavirus was generated in BIV using homologous recombination to introduce the neomycin resistance gene under the control of the ICP18 promoter and the adult globin gene from Bufo marinus under the control of the promoter for the viral MCP into the vIF-2 $\alpha$ locus (Pallister et al. 2007). While not focused on characterizing the function of the vIF- $2 \alpha$ gene, the technology developed in this study facilitated the development of protocols for generating recombinant ranaviruses and confirmed the nonessential nature of the vIF- $2 \alpha$ gene product. 
Building on this study, knock-out (KO) and knock-in (KI) mutants have been generated in ATV, FV3, and RGV (Chen et al. 2011; He et al. 2012b; Huang et al. 2011c; Jancovich and Jacobs 2011). The first step in the generation of KO ranaviruses involves constructing a plasmid that contains a selectable marker flanked by sequences up- and downstream from the targeted gene. Cells are infected with wild type virus and subsequently transfected with the recombination construct. Homologous recombination within the flanking regions surrounding the selectable marker results in replacement of the targeted gene with a gene encoding the selectable marker. Recombinant viruses are isolated by their ability to replicate in the presence of the specific inhibitor (e.g., neomycin or puromycin) or by identifying fluorescent plaques, in those cases in which the green fluorescent protein (GFP) gene was introduced. Since viral and cellular growth are sensitive to neomycin and puromycin treatment, genes that confer resistance to these antibiotics have been used to select successfully KO ranaviruses (Jancovich and Jacobs 2011; Chen et al. 2011). In addition, GFP has been used as a selectable marker (Huang et al., 2011c). Once isolated, characterization of the $\mathrm{KO}$ mutant allows gene function to be determined by changes in phenotype. For example, replication of vIF- $2 \alpha \mathrm{KO}$ mutant in vitro was not significantly altered indicating that vIF- $2 \alpha$ is a nonessential gene (Chen et al. 2011; Jancovich and Jacobs 2011; Pallister et al. 2007). However, when frogs or salamanders were infected with the vIF- $2 \alpha \mathrm{KO}$ mutant, a reduction in host mortality was observed suggesting that vIF-2 $\alpha$ played an important role in vivo. In addition to the vIF $2 \alpha$ homologue, the viral $18 \mathrm{~K}$ immediate early gene has also been targeted (Chen et al. 2011). Deletion of the FV3 18K gene had little impact on viral replication in vitro but resulted in lower mortality in infected tadpoles, again suggesting that this gene was contributing to viral virulence. Preliminary characterization of two additional FV3 KO mutants targeting vCARD and $\beta$ HSD suggested that both were nonessential for replication in vitro ( $\mathrm{J}$ Robert and $\mathrm{G}$ Chen, University of Rochester, and VGC, unpublished observations). Collectively, these studies show the power of KO mutants in ascertaining the role of "nonessential" viral genes.

\subsection{Conditionally Lethal Mutants}

Because loss of an essential gene eliminates a virus's ability to replicate, KO strategies can only be directed against nonessential genes. There are two potential solutions to this impasse: (1) the construction of complementing cell lines that expresses the deleted gene product in trans and thus allow virus replication, and (2) the generation of conditionally lethal $(c l)$ mutants that fully express the targeted gene in the presence of the appropriate inducer (e.g., IPTG or tetracycline), but show little to no expression of the target gene in the absence of the inducer. Conditional lethal mutants have been constructed in African swine fever virus (ASFV, family Asfarviridae) and vaccinia virus (VACV, family Poxviridae; GarciaEscudero et al. 1998; Nichols et al. 2008), two virus families that along with members of the Iridoviridae, Ascoviridae, and Phycodnaviridae families comprise a 
group of phylogenetically related viruses termed, Nuclear Cytoplasmic Large DNA Viruses (Colson et al. 2012; Koonin and Yutin 2010).

Recently, Zhang and her co-workers have used homologous recombination to construct $c l$ mutants targeting the 53R and $2 \mathrm{~L}$ genes of the ranavirus, RGV (He et al. 2012b, 2013, 2014). Briefly, the lacI gene (encoding the lac repressor protein) under the control of the promoter for the ranavirus ICP18 immediate-early gene was introduced into the RGV TK gene by homologous recombination and a recombinant virus designated RGV-lacI was generated. Subsequently, the 53R or $2 \mathrm{~L}$ genes were placed under the control of a hybrid promoter (p50-lacO) in which the lac $O$ sequence (an "operator" sequence which when bound by the lacI repressor protein silences downstream transcription) is located immediately downstream of a TATA-like box within the promoter for RGV gene ORF50. A plasmid containing this construct was introduced into RGV-lacI via homologous recombination to generate the $c l$ mutants, i53R-RGV-lacIO and i2L-RGV-lacIO. In the absence of the inducer, IPTG, the lac repressor binds the lacO sequence and inhibits transcription of the downstream gene. In contrast, when the inducer is present, IPTG binds the repressor and relieves the transcriptional block allowing full expression of the viral gene product. In the case of the 53R and $2 \mathrm{~L} \mathrm{cl}$ mutants, expression of the targeted transcripts and proteins were markedly reduced, but not abolished, in the absence of IPTG. Thus, at $72 \mathrm{~h}$ after infection, virus yields were reduced more than $90 \%$ following a $75 \%$ reduction in the level of 53R transcripts. Similar results were seen with the $2 \mathrm{~L}$ mutant. Taken together these results indicate that both $53 \mathrm{R}$ and $2 \mathrm{~L}$ are essential for replication in vitro and that, as with ASFV and VACV, $c l$ mutants can be used to probe the function of essential viral genes. One potential drawback to their widespread use is that repression of the targeted gene is often not complete. However, as shown with both mutants, unless low level expression of the targeted gene is sufficient for full replication, the repression achieved (in the case of 53R, $75 \%$ at the transcriptional level) is sufficient to ascertain the essential nature of the gene product.

\subsection{Ectopic Expression of Recombinant Viral Proteins}

In addition to $\mathrm{KD}$ studies and studies using $t s, c l$, and $\mathrm{KO}$ mutants, another profitable way in which to explore viral gene function is by ectopically expressing recombinant viral proteins and monitoring their activity. Studies using this approach have been performed to determine the locations and functions of a number of ALRV proteins (e.g., vIF-2 $\alpha, \beta$-HSD, dUTPase, ERV1, 50L, 2L, and 53R) and are summarized immediately below and in Table 2 . The in vitro expression of recombinant viral proteins is especially useful in determining the role of catalytic proteins that impact cellular or immune functions, but less so with viral structural proteins or those that must interact with additional viral proteins for proper functioning.

$v I F-2 \alpha$. vIF-2 $\alpha$, a viral homolog of the alpha subunit of eukaryotic translational initiation factor 2 , is thought to play a critical role in maintaining viral protein 
Table 2 Assessment of Ranavirus gene function using recombinant proteins

\begin{tabular}{|c|c|c|}
\hline Gene (virus and ORF) ${ }^{\mathrm{a}}$ & Phenotype & Reference \\
\hline vIF-2 $\alpha(\mathrm{RCV})$ & $\begin{array}{l}\text { Maintains viral translation by blocking eIF- } 2 \alpha \\
\text { phosphorylation; found among most, but not all, } \\
\text { ranaviruses }\end{array}$ & $\begin{array}{l}\text { Rothenburg et al. } \\
\text { (2011) }\end{array}$ \\
\hline $\begin{array}{l}\text { ICP46 (SGIV ORF } \\
\text { 162L) }\end{array}$ & $\begin{array}{l}\text { Promotes GP cell growth and contributes to } \\
\text { SGIV replication as a structural protein of the } \\
\text { nucleocapsid }\end{array}$ & Xia et al. (2010) \\
\hline $\begin{array}{l}\text { ICP18 (SGIV ORF } \\
\text { 086R) }\end{array}$ & $\begin{array}{l}\text { Promotes GP cell growth and contributes to } \\
\text { SGIV replication as a viral non-envelope protein }\end{array}$ & Xia et al. (2009) \\
\hline $\begin{array}{l}\text { LITAF (SGIV ORF } \\
\text { 136R) }\end{array}$ & $\begin{array}{l}\text { Plays crucial roles in cell death by inducing } \\
\text { apoptosis }\end{array}$ & Huang et al. (2008) \\
\hline $\begin{array}{l}\text { LITAF (FV3 ORF } \\
\text { 75L) }\end{array}$ & $\begin{array}{l}\text { The C-terminal half of ORF 75L is markedly } \\
\text { similar to cellular LITAF; 75L and LITAF } \\
\text { associate in virus-infected cells }\end{array}$ & Eaton et al. (2013) \\
\hline $\begin{array}{l}\text { TNFR (SGIV ORF } \\
\text { 096R) }\end{array}$ & $\begin{array}{l}\text { Contributes to viral replication by modulating } \\
\text { the host apoptotic response }\end{array}$ & Huang et al. (2013b) \\
\hline $\begin{array}{l}\text { dUTPase (SGIV ORF } \\
\text { 049R) }\end{array}$ & Contains a nuclear export signal & Gong et al. (2010) \\
\hline $\begin{array}{l}\text { dUTPase (RGV ORF } \\
\text { 67R) }\end{array}$ & $\begin{array}{l}\text { Regulates levels of dUTP, contributes to } \\
\text { synthesis of dTTP and virus replication }\end{array}$ & Zhao et al. (2007) \\
\hline $\begin{array}{l}\text { H3 binding protein } \\
\text { (SGIV ORF 158L) }\end{array}$ & $\begin{array}{l}\text { Facilitates viral replication, and functions as a } \\
\text { histone } \mathrm{H} 3 \text { chaperone protein to control cellular } \\
\text { gene expression and viral replication }\end{array}$ & Tran et al. (2011b) \\
\hline $\begin{array}{l}\text { Viral Insulin-like } \\
\text { growth factor [IGF] } \\
\text { (SGIV ORF 062R) }\end{array}$ & $\begin{array}{l}\text { Stimulates cell growth and virus replication by } \\
\text { promoting G1/S transition; over-expression } \\
\text { leads to increased apoptosis in non-host cells }\end{array}$ & Yan et al. (2013) \\
\hline $\begin{array}{l}\text { Viral Semaphorin } \\
\text { (SGIV ORF 155R) }\end{array}$ & $\begin{array}{l}\text { Regulates host cytoskeletal structure and, } \\
\text { immune responses; facilitates viral replication. }\end{array}$ & Yan et al. (2014) \\
\hline $\begin{array}{l}\text { VP088 (SGIV ORF } \\
\text { 088) }\end{array}$ & $\begin{array}{l}\text { Plays a role in viral entry as a viral envelope } \\
\text { protein }\end{array}$ & Zhou et al. (2011) \\
\hline $\begin{array}{l}\text { VP019 (SGIV ORF } \\
\text { 019) }\end{array}$ & Viral envelope protein & Huang et al. (2013a) \\
\hline $\begin{array}{l}\text { VP18 (SGIV ORF } \\
\text { 018R) }\end{array}$ & $\begin{array}{l}\text { A putative Ser/Thr kinase; plays critical roles in } \\
\text { virion assembly and expression of viral late } \\
\text { genes }\end{array}$ & Wang et al. (2008a) \\
\hline ORF 38R (SGIV) & $\begin{array}{l}\text { Viral protein with an RGD motif; may play a } \\
\text { role in entry }\end{array}$ & Wan et al. (2010b) \\
\hline ORF 20R (TFV) & $\begin{array}{l}\text { Viral protein with an RGD motif; may play a } \\
\text { role in entry; similar to SGIV ORF } 38 \mathrm{R}\end{array}$ & Wang et al. (2008b) \\
\hline ORF 97R (FV3) & $\begin{array}{l}\text { The ORF 97R product localizes to the ER and } \\
\text { induces invagination of the ER and outer } \\
\text { nuclear membrane into the nucleus }\end{array}$ & Ring et al. (2013) \\
\hline $\begin{array}{l}\beta \text {-HSD (RGV ORF } \\
\text { 52L) }\end{array}$ & $\begin{array}{l}\text { Plays a key role in host steroid synthesis; } \\
\text { overexpression in EPC cells suppresses CPE }\end{array}$ & Sun et al. (2006) \\
\hline $\begin{array}{l}\text { ERV1/ALR (RGV } \\
\text { ORF88R) }\end{array}$ & $\begin{array}{l}\text { A sulfhydryl oxidase; by analogy to its ASFV } \\
\text { homolog, ERV1/ALR is thought to play a key } \\
\text { role in virion assembly }\end{array}$ & Ke et al. (2009) \\
\hline
\end{tabular}


Table 2 (continued)

\begin{tabular}{l|l|l}
\hline Gene (virus and ORF) & Phenotype & Reference \\
\hline 53R (RGV ORF 53R) & $\begin{array}{l}\text { Putative myristoylated membrane protein; plays } \\
\text { a key role in virion formation }\end{array}$ & $\begin{array}{l}\text { Kim et al. (2010), } \\
\text { Zhao et al. (2008) }\end{array}$ \\
\hline 50L (RGV ORF 50L) & $\begin{array}{l}\text { Virion-associated protein, plays roles in virus } \\
\text { assembly and viral gene expression }\end{array}$ & Lei et al. (2012a) \\
\hline 2L (RGV ORF2L) & $\begin{array}{l}\text { Putative membrane protein plays an essential } \\
\text { role in virus replication }\end{array}$ & He et al. (2014) \\
\hline
\end{tabular}

aViral gene products are identified either based on their putative function (e.g., dUTPase) or by reference to their FV3 homolog (e.g., ICP 46). In addition, the virus in which the gene product is found and the specific ORF are indicated. If the function is not known or homology to FV3 is not present, the gene is simply identified by its ORF designation

synthesis in the face of the global translational block triggered by dsRNA-activated PKR. vIF- $2 \alpha$ is hypothesized to act as a pseudosubstrate and, similar to VACV K3L, to bind PKR thereby preventing the phosphorylation and inactivation eIF- $2 \alpha$ (Beattie et al. 1991; Langland and Jacobs 2002). To demonstrate a role for vIF-2 $\alpha$ in maintaining viral protein synthesis in infected cells, Rothenburg et al. (2011) utilized a heterologous yeast system and showed that ectopic expression of vIF- $2 \alpha$ from the ranavirus, Rana catesbeiana virus-Z (RCV-Z), blocked the growth inhibiting effects of human and zebrafish PKR. RCV-Z vIF-2 $\alpha$ was shown to act as an inhibitor of both human and zebrafish PKR and block the PKR-mediated phosphorylation of eIF- $2 \alpha$, whereas VACV K3L displayed host specificity and only blocked the activity of human PKR. Moreover, experiments with vIF-2 $\alpha$ deletion constructs showed that the N-terminal and helical domains were sufficient for PKR inhibition whereas the C-terminal domain was dispensable. Because vIF-2 $\alpha$ does not substitute for eIF- $2 \alpha$ but instead inhibits PKR function, the authors suggested renaming it RIPR, Ranavirus Inhibitor of Protein kinase R. Although this study strengthens the view that vIF- $2 \alpha /$ RIPR is critical for maintaining viral protein synthesis in the face of a shut-off of host translation, it should be noted that both FV3 and soft-shell turtle iridovirus (STIV) encode truncated versions of vIF-2 $\alpha$ that are missing the N-terminal three-fourths of the full length product (Huang et al. 2009; Tan et al. 2004). The ability of both FV3 and STIV to turn off host translation and maintain high levels of viral protein synthesis indicate that although vIF- $2 \alpha$ is important for the maintenance of viral translation in the face of host shut-off, other proteins must also play a part in this process and perhaps, like the E3L/K3L system of VACV, provide a level of redundancy (Langland et al. 2006; Langland and Jacobs 2002).

$\beta H S D$. 3 $\beta$-Hydroxysteroid dehydrogenase plays a key role in cellular steroid synthesis and the corresponding VACV homolog is thought to play a critical role in blunting the host antiviral immune response (Reading et al. 2003). A 1,068 bp/355 amino acid $\beta$-HSD homolog of RGV was cloned and shown to be an immediate-early gene product (Sun et al. 2006). Confocal microscopy revealed that an ectopically expressed $\beta$ HSD-EGFP fusion protein co-localized exclusively with the mitochondrial marker 
pDsRed2-Mito in EPC cells. Moreover, overexpression of $\beta$ HSD-EGFP suppressed RGV-induced cytopathic effect (CPE) in EPC cells. Given the putative role of $\beta \mathrm{HSD}$ in steroid biosynthesis, it is likely that the role of this protein in a productive in vivo infection is to impair the host immune response. Whether $\beta$ HSD plays another role in vitro which allows it to suppress CPE remains to be determined. As seen with VACV mutants that lack $\beta$ HSD (Reading et al. 2003), we hypothesize that mutants targeting the $\beta \mathrm{HSD}$ gene will fail to inhibit the host immune response as fully as $w t$ virus and display an attenuated phenotype in vivo.

dUTPase (dUTP pyrophosphatase): dUTPase is a ubiquitous enzyme responsible for regulating dUTP concentrations (whose incorporation into DNA would be deleterious for virus replication) and raising levels of dTTP via the salvage pathway (Kato et al. 2014; Oliveros et al. 1999). dUTPase catalyzes the conversion of dUTP to dUMP. RGV-encoded dUTPase is a 164 amino acid protein that was characterized as an early gene product by RT-PCR and Western blot analysis. An ectopically expressed dUTPase-EGFP fusion protein was found within the cytoplasm, and immunofluorescence confirmed the cytoplasmic location of dUTPase in productively infected cells (Zhao et al. 2007). Overexpression of dUTPase had no detectable effect on RGV replication suggesting that it did not negatively or positively impact replication in vitro. Thus, at least in EPC cells, dUTPase overexpression does not enhance virus replication, perhaps because the level of expression provided by $w t$ virus is sufficient for full virus replication. In addition, studies of the SGIV dUTPase homolog identified a nuclear export signal that was crucial for the translocation of SGIV dUTPase from the nucleus to the cytoplasm (Gong et al. 2010). Lastly, although BLAST analysis suggests that RGV dUTPase functions in the control of dUTP/dTTP levels, dUTPase genes found within herpesviruses have evolved novel functions including the dysregulation of immune functions (Davison and Stow 2005; Glaser et al. 2006).

ERVI: The yeast protein ERV1 (Essential for Replication and Viability) and its mammalian homolog ALR (Augmenter of Liver Regeneration) are sulfhydryl oxidases that play critical roles in protein folding (Thorpe et al. 2002). Consistent with that role, ASFV contains an ERV1/ALR homolog, 9GL that is found within viral factories and plays a critical role in virion maturation (Lewis et al. 2000). A 9GL deletion mutant displayed a 2-log drop in viral yield, and, of the virions that formed, 90-99 \% contained acentric nucleoid structures. Like ASFV, the RGV ERV1 homo$\log (88 \mathrm{R})$ is a late protein (Ke et al. 2009). It contains the highly conserved ERV1 motif Cys-X-X-Cys and was detected in both the nucleus and cytoplasm. However, unlike the ASFV ERV1/ALR KO mutant, knock down of 88R expression by RNAi did not result in a drop in virus yield, suggesting either that ERV1 plays another role in virus replication, knock down was incomplete, or host cells retained sufficient sulfhydryl oxidase capacity to compensate for any defect in the viral enzyme.

50L: RGV 50L encodes a protein 499 amino acids in length with a predicted mol wt of $55.5 \mathrm{kDa}$. Full-length homologs ranging in size from 499 (STIV)—541 (EHNV) amino acids are present in a variety of ranaviruses, whereas a shorter homolog of 
249 amino acids encompassing only the C-terminal half of the protein is found in FV3. RGV 50L was cloned, expressed in E. coli, and used to prepare anti-50L antibody in mice. In addition, 50L was cloned into the eukaryotic expression vector pcDNA3.1, to yield 50L-pcDNA3.1 (Lei et al. 2012a). Immunofluorescent staining detected 50L within the cytoplasm, viral assembly sites, and nucleus. Moreover, the presence of 50L within the nucleus was dependent upon a nuclear localization signal within the central region of the protein. Infection of cells transfected with 50L-pcDNA3.1 displayed higher levels of 53R mRNA suggesting that 50L expression may affect the expression of RGV genes.

LITAF: Both SGIV and FV3 encode proteins with homology to a cellular protein designated LITAF, LPS-induced TNF $\alpha$ factor. LPS is a potent stimulator of monocytes and macrophages and triggers the secretion of TNF $\alpha$ and other proinflammatory cytokines. LITAF was identified as a novel transcriptional factor that modulated TNF $\alpha$ expression and played a role in the regulation of inflammatory cytokines (Tang et al. 2006). SGIV ORF136 encodes an early viral gene product that is a homolog of LITAF and which, following transfection of grouper cells with a vector expressing ORF136, is predominantly associated with mitochondria. Overexpression of SGIV LITAF in vitro induces apoptosis, as shown by increased apoptotic bodies, depolarization of mitochondrial membrane potential, and activation of caspase-3, suggesting that SGIV LITAF might play crucial roles in SGIVinduced cell death (Huang et al. 2008). Similar to SGIV ORF136, FV3 ORF 75L encodes a protein that shows high sequence similarity to a conserved domain found in the C-terminal half of cellular LITAF (Eaton et al. 2013). Following cotransfection or viral infection, cellular LITAF and FV3 75L were shown to co-localize to late endosomes/lysosomes within both baby green monkey cells (BGMK) and A6 amphibian cells. Interestingly, reexamination of SGIV ORF 136 confirmed localization to mitochondria within BGMK cells, but showed that, as with FV3 75L, SGIV ORF 136 localized to endosomes/lysosomes in amphibian A6 cells. To date, the exact function and temporal class of the viral LITAF homologs remain uncertain. It has been suggested that viral LITAF acts in a dominant-negative fashion to block the function of cellular LITAF (Eaton et al. 2013). If cellular LITAF does have an antiviral function, RNAi or asMO knock down of cellular LITAF levels should generate higher titers of FV3 in vitro and suggest a role for its viral homolog. Alternatively in vivo infection with a LITAF knock out mutant should result in an attenuated infection and lower viral titers.

RGD motif-containing proteins: Proteins containing the RGD motif are present among all iridovirid genera and include SGIV VP38 (Wan et al. 2010), Tiger frog virus ORF 20R (Wang et al. 2008b), and yellow croaker iridovirus (YCIV, genus Megalocytivirus) 037L (Ao and Chen 2006). Although differing markedly in size, all three genes contain an RGD motif that has been reported to play an important role in virus attachment and entry. In all three studies, recombinant protein was used to generate specific antiserum that was used to identify the protein within viral assembly sites and the viral envelope. Collectively, these studies indicate that RGDcontaining proteins are found within viral assembly sites and envelopes and may play 
a role in subsequent viral entry. However, suggestive of other roles, a YCIV-encoded thioredoxin-037L fusion protein was shown to induce cell rounding, detachment, and aggregation following its transfection into BF-2 cell monolayers. Additional ranavirus ORFs whose functions have been explored using recombinant proteins are described briefly below and summarized in Table 2 .

Additional Recombinant SGIV- and ISKNV-encoded Proteins. Vectors expressing the SGIV immediate-early (IE) genes, ORF162L and ORF086R, encoding putative homologs of FV3 ICP46 and ICP18, respectively, were constructed. Both gene products are distributed predominantly within the cytoplasm, and their overexpression promoted the growth of grouper embryonic cells and contributed to SGIV replication. SGIV ORF096 (VP96) encodes a putative homolog of TNFR, which contains two extracellular cysteine-rich domains (CRDs) but lacks the C-terminal transmembrane domain. Overexpression of ORF096 in vitro enhances cellular proliferation and improves cell survival suggesting that SGIV might utilize a viral homolog of TNFR to modulate the host apoptotic response for effective replication (Huang et al. 2013b). As with RGV, SGIV encodes a dUTPase homolog (ORF049R) with a leucine-rich nuclear export signal (NES) at its C-terminus. SGIV dUTPase is a cytoplasmic protein, and its NES is crucial for the translocation of dUTPase from the nucleus to the cytoplasm (Gong et al. 2010). SGIV ORF158L is observed in nuclei and virus assembly sites and its knock-down results in a significant decrease in virus yield in grouper embryonic (GP) cells. Further, analysis suggests that ORF158L may function as a histone $\mathrm{H} 3$ chaperon, enabling it to control host cellular gene expression and facilitate viral replication (Tran et al. 2011). ORF 158L is not found in all ranaviruses, but homologs displaying approximately $33 \%$ similarity to the SGIV product are found in EHNV, ADRV, and CMTV. SGIV ORF062R encodes a novel insulinlike growth factor that stimulates the growth of grouper GP cells and perhaps SGIV replication by promoting G1/S phase transition. In addition, overexpression of ORF062R slightly increased apoptosis in SGIV-infected non-host FHM cells (Yan et al. 2013). SGIV ORF155R encodes a semaphorin homolog, which could promote viral replication in vitro and attenuate the cellular immune response. Ectopically expressed ORF155R was shown to alter the cytoskeletal structure of fish cells. This alteration was characterized by a circumferential ring of microtubules near the nucleus and a disrupted microfilament organization (Yan et al. 2014). An abundant viral protein, ORF018R, has been identified which may play critical roles in serine/ threonine phosphorylation and virion assembly (Wang et al. 2008a). Two late genes, SGIV ORF088 and ORF019, encode viral envelope proteins. Furthermore, rVP88 was shown to bind a $94 \mathrm{kDa}$ host cell membrane protein, suggesting that VP88 might function as an attachment protein and play a role in viral entry (Huang et al. 2013a; Zhou et al. 2011). Finally, similar approaches have been applied to ISKNV (genus Megalocytivirus) and used to identify putative functions among a viral TRAF protein (He et al. 2012a), a viral protein that mediates formation of a mock basement membrane and provides attachment sites for lymphatic endothelial cells (Xu et al. 2010), a viral ankyrin repeat protein that may inhibit TNF $\alpha$-induced NF- $\kappa B$ signaling (Guo et al. 2011a), and a viral-encoded vascular endothelial growth factor 
(Wang et al. 2008c). Collectively, the generation and expression of recombinant viral proteins provides a powerful methodology for determining the cellular location and putative function of virus-encoded proteins.

\section{Final Thoughts}

Using contemporary molecular techniques, researchers are slowly elucidating the specific steps by which ranaviruses replicate in vitro and trigger disease in vivo. This work has been facilitated by pioneering studies performed with herpesviruses, poxviruses, and ASFV that have provided insights into which viral genes play important roles in virus replication and disease progression. Optimistically, identification of ranavirus genes that contribute to enhanced virus replication and the evasion of host immune responses will allow us to construct vaccines that are able to effectively protect endangered amphibians, fish, and reptiles. Success in this area is critical given the ongoing decline of amphibians in many parts of the world and the growing reliance upon mariculture and aquaculture as a source of protein for human consumption. In addition, understanding how viral genes interact and modulate immunological responses will broaden our understanding of immunity among "lower vertebrates" and shed light on the origins of the immune system.

Acknowledgments We thank Richard Condit (University of Florida) and Jacques Robert (University of Rochester Medical Center) for their careful review of this manuscript. This work was partially funded by the National Science Foundation (Award No. IOS 07-42711) and The University of Mississippi Medical Center (VGC); the National Major Basic Research Program (Award No. 2010CB126303), the National Natural Science Foundation of China (Award No. 31270213), and the Project of the State Key Laboratory of Freshwater Ecology and Biotechnology (Award No. 2011FBZ12) (QZ); the National Basic Research Program of China (973 Program, Award No. 2012CB114402), and the National Natural Science Foundation of China (Award No. 31330082) (QQ); and US National Institutes of Health (NIH) award 1R15-AI-101889-01 (JKJ).

Open Access publication was made possible through grants provided by the University of Tennessee (Institute of Agriculture, Office of Research and Engagement, and Department of Forestry, Wildlife and Fisheries), Washington State University Libraries, Gordon State College (Office of Academic Affairs), the Association of Reptilian and Amphibian Veterinarians, and the Amphibian and Reptile Conservancy.

Open Access This chapter is distributed under the terms of the Creative Commons Attribution Noncommercial License, which permits any noncommercial use, distribution, and reproduction in any medium, provided the original author(s) and source are credited.

\section{References}

Ao J, Chen X (2006) Identification and characterization of a novel gene encoding an RGDcontaining protein in large yellow croaker iridovirus. Virology 355:213-222

Babu SG, Pandeya A, Verma N, Shukla N, Kumar RV, Saxena S (2014) Role of HCMV miR-UL70-3p and miR-UL148D in overcoming the cellular apoptosis. Mol Cell Biochem 393:89-98 
Beattie E, Tartaglia J, Paoletti E (1991) Vaccinia virus-encoded eIF-2 alpha homolog abrogates the antiviral effect of interferon. Virology 183:419-422

Braunwald J, Tripier F, Kirn A (1979) Comparison of the properties of enveloped and naked frog virus 3 (FV3) particles. J Gen Virol 45:673-682

Braunwald J, Nonnenmacher H, Tripier-Darcy F (1985) Ultrastructural and biochemical study of frog virus 3 uptake by BHK-21 cells. J Gen Virol 66(pt 2):283-293

Brodie R, Roper RL, Upton C (2004) JDotter: a JAVA interface to multiple display plots generated by dotter. Bioinformatics 20:279-281

Brunner JL, Storfer A, Gray MJ, Hoverman JT (2015) Ranavirus ecology and evolution: from epidemiology to extinction. In: Gray MJ, Chinchar VG (eds) Ranaviruses: lethal pathogens of ectothermic vertebrates. Springer, New York

Caipang CM, Hirono I, Aoki T (2006a) Immunogenicity, retention and protective effects of the protein derivatives of formalin-inactivated red seabream iridovirus (RSIV) vaccine in red seabream, Pagrus major. Fish Shellfish Immunol 20:597-609

Caipang CM, Takano T, Hirono I, Aoki T (2006b) Genetic vaccines protect red seabream, Pagrus major, upon challenge with red seabream iridovirus (RSIV). Fish Shellfish Immunol 21:130-138

Cardone G, Winkler DC, Trus BL, Cheng N, Heuser JE, Newcomb WW, Brown JC, Steven AC (2007) Visualization of the herpes simplex virus portal in situ by cryo-electron tomography. Virology 361:426-434

Chabaud S, Sasseville AM, Elahi SM, Caron A, Dufour F, Massie B, Langelier Y (2007) The ribonucleotide reductase domain of the $\mathrm{R} 1$ subunit of herpes simplex virus type 2 ribonucleotide reductase is essential for R1 antiapoptotic function. J Gen Virol 88:384-394

Chang JT, Schmid MF, Rixon FJ, Chiu W (2007) Electron cryotomography reveals the portal in the herpesvirus capsid. J Virol 81:2065-2068

Chen LM, Wang F, Song W, Hew CL (2006) Temporal and differential gene expression of Singapore grouper iridovirus. J Gen Virol 87:2907-2915

Chen G, Ward BM, Yu KH, Chinchar VG, Robert J (2011) Improved knockout methodology reveals that Frog virus 3 mutants lacking either the $18 \mathrm{~K}$ immediate-early gene or the truncated $v I F-2$ alpha gene are defective for replication in vivo. J Virol 85:11131-11138

Chen Z, Gui J, Gao X, Pei C, Hong Y, Zhang Q (2013) Genome architecture changes and major gene variations of Andrias davidianus ranavirus (ADRV). Vet Res 44:101

Cheng K, Escalon BL, Robert J, Chinchar VG, Garcia-Reyero N (2014) Differential transcription of fathead minnow immune-related genes following infection with frog virus 3 , an emerging pathogen of ectothermic vertebrates. Virology 456-457:77-86

Chinchar VG, Granoff A (1984) Isolation and characterization of a frog virus 3 variant resistant to phosphonoacetate: genetic evidence for a virus-specific DNA polymerase. Virology 138:357-361

Chinchar VG, Granoff A (1986) Temperature-sensitive mutants of frog virus 3: biochemical and genetic characterization. J Virol 58:192-202

Chinchar VG, Yu W (1990a) Frog virus 3-mediated translational shut-off: frog virus 3 messages are translationally more efficient than host and heterologous viral messages under conditions of increased translational stress. Virus Res 16:163-174

Chinchar VG, Yu W (1990b) Translational efficiency: iridovirus early mRNAs outcompete tobacco mosaic virus message in vitro. Biochem Biophys Res Commun 172:1357-1363

Chinchar VG, Goorha R, Granoff A (1984) Early proteins are required for the formation of frog virus 3 assembly sites. Virology 135:148-156

Chinchar VG, Bryan L, Wang J, Long S, Chinchar GD (2003) Induction of apoptosis in frog virus 3-infected cells. Virology 306:303-312

Chinchar VG, Hyatt A, Miyazaki T, Williams T (2009) Family Iridoviridae : poor viral relations no longer. Curr Top Microbiol Immunol 328:123-170

Chinchar VG, Yu KH, Jancovich JK (2011) The molecular biology of frog virus 3 and other iridoviruses infecting cold-blooded vertebrates. Viruses 3:1959-1985

Colson P, de Lamballerie X, Fournous G, Raoult D (2012) Reclassification of giant viruses composing a fourth domain of life in the new order Megavirales. Intervirology 55:321-332 
Conner J, Cross A, Murray J, Marsden H (1994a) Identification of structural domains within the large subunit of herpes simplex virus ribonucleotide reductase. J Gen Virol 75(pt 12): $3327-3335$

Conner J, Marsden H, Clements BH (1994b) Ribonucleotide reductase of herpesviruses. Rev Med Virol 4:25-34

Cordier O, Aubertin AM, Lopez C, Tondre L (1981) Inhibitiion de la traduction par le FV3: action des proteines virales de structure solubilisees sur la synthese proteique in vivo et in vitro. Ann Virol (Inst Pasteur) 132 E:25-39

Daikoku T, Yamamoto N, Maeno K, Nishiyama Y (1991) Role of viral ribonucleotide reductase in the increase of dTTP pool size in herpes simplex virus-infected Vero cells. J Virol 72:1441-1444

Dang LT, Kondo H, Hirono I, Aoki T (2008) Inhibition of red seabream iridovirus (RSIV) replication by small interfering RNA (siRNA) in a cell culture system. Antiviral Res 77:142-149

Darcy-Tripier F, Nermut MV, Braunwald J, Williams LD (1984) The organization of frog virus 3 as revealed by freeze-etching. Virology 138:287-299

Davison AJ, Stow ND (2005) New genes from old: redeployment of dUTPase by herpesviruses. J Virol 79:12880-12892

de Wind N, Berns A, Gielkens A, Kimman T (1993) Ribonucleotide reductase-deficient mutants of pseudorabies virus are avirulent for pigs and induce partial protective immunity. J Gen Virol 74(pt 3):351-359

Devauchelle G, Stoltz DB, Darcy-Tripier F (1985) Comparative ultrastructure of iridoviridae. Curr Top Microbiol Immunol 116:1-21

Duffus ALJ, Waltzek TB, Stöhr AC, Allender MC, Gotesman M, Whittington RJ, Hick P, Hines MK, Marschang RE (2015) Distribution and host range of ranaviruses. In: Gray MJ, Chinchar VG (eds) Ranaviruses: lethal pathogens of ectothermic vertebrates. Springer, New York

Eaton HE, Metcalf J, Penny E, Tcherepanov V, Upton C, Brunetti CR (2007) Comparative genomic analysis of the family Iridoviridae: re-annotating and defining the core set of iridovirus genes. Virol J 4:11

Eaton HE, Ring BA, Brunetti CR (2010) The genomic diversity and phylogenetic relationship in the family iridoviridae. Viruses 2:1458-1475

Eaton HE, Ferreira Lacerda A, Desrochers G, Metcalf J, Angers A, Brunetti CR (2013) Cellular LITAF interacts with frog virus $375 \mathrm{~L}$ protein and alters its subcellular localization. J Virol 87:716-723

Eberhardt MK, Deshpande A, Chang WL, Barthold SW, Walter MR, Barry PA (2013) Vaccination against a virus-encoded cytokine significantly restricts viral challenge. J Virol 87:11323-11331

Essani K, Goorha R, Granoff A (1987) Mutation in a DNA-binding protein reveals an association between DNA-methyltransferase activity and a 26,000-Da polypeptide in frog virus 3-infected cells. Virology 161:211-217

Feighny RJ, Henry BE II, Pagano JS (1981) Epstein-Barr virus-induced deoxynuclease and the reutilization of host-cell DNA degradation products in viral DNA replication. Virology 115:395-400

Fu JP, Chen SN, Zou PF, Huang B, Guo Z, Zeng LB, Qin QW, Nie P (2014) IFN-gamma in turtle: conservation in sequence and signalling and role in inhibiting iridovirus replication in Chinese soft-shelled turtle Pelodiscus sinensis. Dev Comp Immunol 43:87-95

Gammon DB, Gowrsihankar B, Duraffour S, Andrei G, Upton C, Evans DH (2010) Vaccinia virusencoded ribonucleotide reductase subunits are differentially required for replication and pathogenesis. PLoS Pathog 6:e1000984

Gantress J, Maniero GD, Cohen N, Robert J (2003) Development and characterization of a model system to study amphibian immune responses to iridoviruses. Virology 311:254-262

Garcia-Escudero R, Andres G, Almazan F, Vinuela E (1998) Inducible gene expression from African swine fever virus recombinants: analysis of the major capsid protein p72. J Virol $72: 3185-3195$

Gendrault JL, Steffan AM, Bingen A, Kirn A (1981) Penetration and uncoating of frog virus 3 (FV3) in cultured rat Kupffer cells. Virology 112:375-384 
Glaser R, Litsky ML, Padgett DA, Baiocchi RA, Yang EV, Chen M, Yeh PE, Green-Church KB, Caligiuri MA, Williams MV (2006) EBV-encoded dUTPase induces immune dysregulation: implications for the pathophysiology of EBV-associated disease. Virology 346:205-218

Gong J, Huang YH, Huang XH, Zhang R, Qin QW (2010) Nuclear-export-signal-dependent protein translocation of dUTPase encoded by Singapore grouper iridovirus. Arch Virol 155:1069-1076

Goorha R (1981) Frog virus 3 requires RNA polymerase II for its replication. J Virol 37:496-499

Goorha R (1982) Frog virus 3 DNA replication occurs in two stages. J Virol 43:519-528

Goorha R, Dixit P (1984) A temperature-sensitive (TS) mutant of frog virus 3 (FV3) is defective in second-stage DNA replication. Virology 136:186-195

Goorha R, Granoff A (1979) Icosahedral cytoplasmic deoxyriboviruses. In: Fraenkel-Conrat H, Wagner RR (eds) Comprehensive virology. Plenum Press, New York, pp 347-399

Goorha R, Murti KG (1982) The genome of frog virus 3, an animal DNA virus, is circularly permuted and terminally redundant. Proc Natl Acad Sci U S A 79:248-252

Goorha R, Willis DB, Granoff A, Naegele RF (1981) Characterization of a temperature-sensitive mutant of frog virus 3 defective in DNA replication. Virology 112:40-48

Goorha R, Granoff A, Willis DB, Murti KG (1984) The role of DNA methylation in virus replication: inhibition of frog virus 3 replication by 5-azacytidine. Virology 138:94-102

Grayfer L, De Jesús Andino F, Robert J (2014) The amphibian (Xenopus laevis) type I interferon response to Frog Virus 3: new insight into ranavirus pathogenicity. J Virol 88:5766-5777

Grayfer L, Edholm E-S, De Jesús Andino F, Chinchar VG, Robert J (2015) Ranavirus host immunity and immune evasion. In: Gray MJ, Chinchar VG (eds) Ranaviruses: lethal pathogens of ectothermic vertebrates. Springer, New York

Guo CJ, Chen WJ, Yuan LQ, Yang LS, Weng SP, Yu XQ, He JG (2011a) The viral ankyrin repeat protein (ORF124L) from infectious spleen and kidney necrosis virus attenuates nuclear factor\{kappa\}B activation and interacts with I $\{$ kappa\}B kinase \{beta\}. J Gen Virol 92:1561-1570

Guo CJ, Liu D, Wu YY, Yang XB, Yang LS, Mi S, Huang YX, Luo YW, Jia KT, Liu ZY, Chen WJ, Weng SP, Yu XQ, He JG (2011b) Entry of tiger frog virus (an Iridovirus) into HepG2 cells via a pH-dependent, atypical, caveola-mediated endocytosis pathway. J Virol 85:6416-6426

Guo CJ, Wu YY, Yang LS, Yang XB, He J, Mi S, Jia KT, Weng SP, Yu XQ, He JG (2012) Infectious spleen and kidney necrosis virus (a fish iridovirus) enters Mandarin fish fry cells via caveoladependent endocytosis. J Virol 86:2621-2631

Guo C, Yan Y, Cui H, Huang X, Qin Q (2013) miR-homoHSV of Singapore grouper iridovirus (SGIV) inhibits expression of the SGIV pro-apoptotic factor LITAF and attenuates cell death. PLoS One 8:e83027

Hannon GJ (2002) RNA interference. Nature 418:244-251

He BL, Yuan JM, Yang LY, Xie JF, Weng SP, Yu XQ, He JG (2012a) The viral TRAF protein (ORF111L) from infectious spleen and kidney necrosis virus interacts with TRADD and induces caspase 8-mediated apoptosis. PLoS One 7:e37001

He LB, Ke F, Zhang QY (2012b) Rana grylio virus as a vector for foreign gene expression in fish cells. Virus Res 163:66-73

He LB, Gao XC, Ke F, Zhang QY (2013) A conditional lethal mutation in Rana grylio virus ORF 53R resulted in a marked reduction in virion formation. Virus Res 177:194-200

He LB, Ke F, Wang J, Gao XC, Zhang QY (2014) Rana grylio virus (RGV) envelope protein 2L: subcellular localization and essential roles in virus infectivity revealed by conditional lethal mutant. J Gen Virol 95:679-690

Hoelzer K, Shackelton LA, Parrish CR (2008) Presence and role of cytosine methylation in DNA viruses of animals. Nucleic Acids Res 36:2825-2837

Hook LM, Grey F, Grabski R, Tirabassi R, Doyle T, Hancock M, Landais I, Jeng S, McWeeney S, Britt W, Nelson JA (2014) Cytomegalovirus miRNAs target secretory pathway genes to facilitate formation of the virion assembly compartment and reduce cytokine secretion. Cell Host Microbe 15:363-373

Huang X, Huang Y, Gong J, Yan Y, Qin Q (2008) Identification and characterization of a putative lipopolysaccharide-induced TNF-alpha factor (LITAF) homolog from Singapore grouper iridovirus. Biochem Biophys Res Commun 373:140-145 
Huang Y, Huang X, Liu H, Gong J, Ouyang Z, Cui H, Cao J, Zhao Y, Wang X, Jiang Y, Qin Q (2009) Complete sequence determination of a novel reptile iridovirus isolated from soft-shelled turtle and evolutionary analysis of Iridoviridae. BMC Genomics 10:224

Huang X, Huang Y, OuYang Z, Cai J, Yan Y, Qin Q (2011a) Roles of stress-activated protein kinases in the replication of Singapore grouper iridovirus and regulation of the inflammatory responses in grouper cells. J Gen Virol 92:1292-1301

Huang X, Huang Y, Ouyang Z, Xu L, Yan Y, Cui H, Han X, Qin Q (2011b) Singapore grouper iridovirus, a large DNA virus, induces nonapoptotic cell death by a cell type dependent fashion and evokes ERK signaling. Apoptosis 16:831-845

Huang Y, Huang X, Cai J, Ye F, Guan L, Liu H, Qin Q (2011c) Construction of green fluorescent protein-tagged recombinant iridovirus to assess viral replication. Virus Res 160:221-229

Huang X, Gong J, Huang Y, Ouyang Z, Wang S, Chen X, Qin Q (2013a) Characterization of an envelope gene VP19 from Singapore grouper iridovirus. Virol J 10:354

Huang X, Huang Y, Cai J, Wei S, Gao R, Qin Q (2013b) Identification and characterization of a tumor necrosis factor receptor like protein encoded by Singapore grouper iridovirus. Virus Res 178:340-348

Hudziak RM, Summerton J, Weller DD, Iversen PL (2000) Antiproliferative effects of steric blocking phosphorodiamidate morpholino antisense agents directed against c-myc. Antisense Nucleic Acid Drug Dev 10:163-176

Jancovich JK, Bremont M, Touchman JW, Jacobs BL (2010) Evidence for multiple recent host species shifts among the ranaviruses (Family Iridoviridae). J. Virol. 84:2636-2647

Jancovich JK, Jacobs BL (2011) Innate immune evasion mediated by the Ambystoma tigrinum virus eukaryotic translation initiation factor 2 alpha homologue. J Virol 85:5061-5069

Jancovich JK, Mao J, Chinchar VG, Wyatt C, Case ST, Kumar S, Valente G, Subramanian S, Davidson EW, Collins JP, Jacobs BL (2003) Genomic sequence of a ranavirus (family Iridoviridae) associated with salamander mortalities in North America. Virology 316:90-103

Jancovich JK, Chinchar VG, Hyatt A, Miyazaki T, Williams T, Zhang QY (2012) Family Iridoviridae. In: King AMQ, Adams MJ, Carstens EB, Lefkowitz EJ (eds) Virus taxonomy: classification and nomenclature of viruses. Ninth report of the International Committee on Taxonomy of Viruses. Elsevier, Amsterdam, pp 193-210

Jancovich JK, Steckler N, Waltzek TB (2015) Ranavirus taxonomy and phylogeny. In: Gray MJ, Chinchar VG (eds) Ranaviruses: lethal pathogens of ectothermic vertebrates. Springer, New York

Jia KT, Wu YY, Liu ZY, Mi S, Zheng YW, He J, Weng SP, Li SC, He JG, Guo CJ (2013) Mandarin fish caveolin 1 interaction with major capsid protein of infectious spleen and kidney necrosis virus and its role in early stages of infection. J Virol 87:3027-3038

Johnston JB, McFadden G (2003) Poxvirus immunomodulatory strategies: current perspectives. J Virol 77:6093-6100

Johnston JB, McFadden G (2004) Technical knockout: understanding poxvirus pathogenesis by selectively deleting viral immunomodulatory genes. Cell Microbiol 6:695-705

Johnston JB, Barrett JW, Nazarian SH, Goodwin M, Ricciuto D, Wang G, McFadden G (2005) A poxvirus-encoded pyrin domain protein interacts with ASC-1 to inhibit host inflammatory and apoptotic responses to infection. Immunity 23:587-598

Kato A, Hirohata Y, Arii J, Kawaguchi Y (2014) Phosphorylation of herpes simplex virus 1 dUTPase up-regulated viral dUTPase activity to compensate for low cellular dUTPase activity for efficient viral replication. J Virol 88:7776-7785

Kaur K, Rohozinski J, Goorha R (1995) Identification and characterization of the frog virus 3 DNA methyltransferase gene. J Gen Virol 76(pt 8):1937-1943

Ke F, Zhao L, Zhang QY (2009) Cloning, expression and subcellular distribution of a Rana grylio virus late gene encoding ERV1 homologue. Mol Biol Report 36:1651-1659

Kim YS, Ke F, Lei XY, Zhu R, Zhang QY (2010) Viral envelope protein 53R gene highly specific silencing and iridovirus resistance in fish cells by AmiRNA. PLoS One 5:e10308

Koonin EV, Yutin N (2010) Origin and evolution of eukaryotic large nucleo-cytoplasmic DNA viruses. Intervirology 53:284-292 
Krug A, Towarowski A, Britsch S, Rothenfusser S, Hornung V, Bals R, Giese T, Engelmann H, Endres S, Krieg AM, Hartmann G (2001) Toll-like receptor expression reveals CpG DNA as a unique microbial stimulus for plasmacytoid dendritic cells which synergizes with CD40 ligand to induce high amounts of IL-12. Eur J Immunol 31:3026-3037

Krug A, Luker GD, Barchet W, Leib DA, Akira S, Colonna M (2004) Herpes simplex virus type 1 activates murine natural interferon-producing cells through toll-like receptor 9. Blood 103:1433-1437

Langelier Y, Bergeron S, Chabaud S, Lippens J, Guilbault C, Sasseville AM, Denis S, Mosser DD, Massie B (2002) The R1 subunit of herpes simplex virus ribonucleotide reductase protects cells against apoptosis at, or upstream of, caspase-8 activation. J Gen Virol 83:2779-2789

Langland JO, Jacobs BL (2002) The role of the PKR-inhibitory genes, E3L and K3L, in determining vaccinia virus host range. Virology 299:133-141

Langland JO, Cameron JM, Heck MC, Jancovich JK, Jacobs BL (2006) Inhibition of PKR by RNA and DNA viruses. Virus Res 119:100-110

Lei XY, Ou T, Zhang QY (2012a) Rana grylio virus (RGV) 50L is associated with viral matrix and exhibited two distribution patterns. PLoS One 7:e43033

Lei XY, Ou T, Zhu RL, Zhang QY (2012b) Sequencing and analysis of the complete genome of Rana grylio virus (RGV). Arch Virol 157:1559-1564

Lembo D, Brune W (2009) Tinkering with a viral ribonucleotide reductase. Trends Biochem Sci 34:25-32

Lewis T, Zsak L, Burrage TG, Lu Z, Kutish GF, Neilan JG, Rock DL (2000) An African swine fever virus ERV1-ALR homologue, 9GL, affects virion maturation and viral growth in macrophages and viral virulence in swine. J Virol 74:1275-1285

Lin PW, Huang YJ, John JA, Chang YN, Yuan CH, Chen WY, Yeh CH, Shen ST, Lin FP, Tsui WH, Chang CY (2008) Iridovirus Bcl-2 protein inhibits apoptosis in the early stage of viral infection. Apoptosis 13:165-176

Ma J, Zeng L, Zhou Y, Fiang N, Zhang H, Fan Y, Meng Y, Xu J (2014) Ultrastructural morphogenesis of an amphibian iridovirus isolated from Chinese giant salamander (Andrias davidianus). J Comp Pathol 150:325-331

Majji S, Thodima V, Sample R, Whitley D, Deng Y, Mao J, Chinchar VG (2009) Transcriptome analysis of Frog virus 3, the type species of the genus Ranavirus, family Iridoviridae. Virology 391:293-303

Maniero GD, Morales H, Gantress J, Robert J (2006) Generation of a long-lasting, protective, and neutralizing antibody response to the ranavirus FV3 by the frog Xenopus. Dev Comp Immunol 30:649-657

Mavian C, Lopez-Bueno A, Balseiro A, Casais R, Alcami A, Alejo A (2012) The genome sequence of the emerging common midwife toad virus identifies an evolutionary intermediate within ranaviruses. J Virol 86:3617-3625

Moody NJG, Owens L (1994) Experimental demonstration of pathogenicity of a frog virus, Bohle iridovirus, for a fish species, barramundi Lates Calcarifer. Dis Aquat Organ 18:95-102

Morales HD, Robert J (2007) Characterization of primary and memory CD8 T-cell responses against ranavirus (FV3) in Xenopus laevis. J Virol 81:2240-2248

Morales HD, Abramowitz L, Gertz J, Sowa J, Vogel A, Robert J (2010) Innate immune responses and permissiveness to ranavirus infection of peritoneal leukocytes in the frog Xenopus laevis. J Virol 84:4912-4922

Morrison EA, Garner S, Echaubard P, Lesbarreres D, Kyle CJ, Brunetti CR (2014) Complete genome analysis of a frog virus 3 (FV3) isolate and sequence comparison with isolates of differing levels of virulence. Virol J 11:46

Murti KG, Goorha R, Chen M (1985) Interaction of frog virus 3 with the cytoskeleton. Curr Top Microbiol Immunol 116:107-131

Murti KG, Goorha R, Klymkowsky MW (1988) A functional role for intermediate filaments in the formation of frog virus 3 assembly sites. Virology 162:264-269 
Naegele RF, Granoff A (1971) Viruses and renal cancinoma of Rana pipiens. XI. Isolation of Frog virus 3 temperature-sensitive mutants; complementation and genetic recombination. Virology 44:286-295

Nichols RJ, Stanitsa E, Unger B, Traktman P (2008) The vaccinia virus gene I2L encodes a membrane protein with an essential role in virion entry. J Virol 82:10247-10261

Oliveros M, Garcia-Escudero R, Alejo A, Vinuela E, Salas ML, Salas J (1999) African swine fever virus dUTPase is a highly specific enzyme required for efficient replication in swine macrophages. J Virol 73:8934-8943

Ou-yang Z, Wang P, Huang X, Cai J, Huang Y, Wei S, Ji H, Wei J, Zhou Y, Qin Q (2012) Immunogenicity and protective effects of inactivated Singapore grouper iridovirus (SGIV) vaccines in orange-spotted grouper, Epinephelus coioides. Dev Comp Immunol 38:254-261

Pallister J, Goldie S, Coupar B, Shiell B, Michalski WP, Siddon N, Hyatt A (2007) Bohle iridovirus as a vector for heterologous gene expression. J Virol Methods 146:419-423

Pavelin J, Reynolds N, Chiweshe S, Wu G, Tiribassi R, Grey F (2013) Systematic microRNA analysis identifies ATP6V0C as an essential host factor for human cytomegalovirus replication. PLoS Pathog 9:e1003820

Pham PH, Lai YS, Lee FF, Bols NC, Chiou PP (2012) Differential viral propagation and induction of apoptosis by grouper iridovirus (GIV) in cell lines from three non-host species. Virus Res 167:16-25

Purifoy D, Naegele RF, Granoff A (1973) Viruses and renal carcinoma of Rana pipiens. XIV. Temperature-sensitive mutants of frog virus 3 with defective encapsidation. Virology 54:525-535

Raghow R, Granoff A (1979) Macromolecular synthesis in cells infected by frog virus 3. X. Inhibition of cellular protein synthesis by heat-inactivated virus. Virology 98:319-327

Reading PC, Moore JB, Smith GL (2003) Steroid hormone synthesis by vaccinia virus suppresses the inflammatory response to infection. J Exp Med 197:1269-1278

Ring BA, Ferreira Lacerda A, Drummond DJ, Wangen C, Eaton HE, Brunetti CR (2013) Frog virus 3 open reading frame 97R localizes to the endoplasmic reticulum and induces nuclear invaginations. J Virol 87:9199-9207

Robert J (2010) Emerging ranaviral infectious diseases and amphibian decline. Diversity 2:314-330

Robert J, Morales H, Buck W, Cohen N, Marr S, Gantress J (2005) Adaptive immunity and histopathology in frog virus 3-infected Xenopus. Virology 332:667-675

Rothenburg S, Chinchar VG, Dever TE (2011) Characterization of a ranavirus inhibitor of the antiviral protein kinase PKR. BMC Microbiol 11:56

Rouiller I, Brookes SM, Hyatt AD, Windsor M, Wileman T (1998) African swine fever virus is wrapped by the endoplasmic reticulum. J Virol 72:2373-2387

Sample R (2010) Elucidation of Frog Virus 3 gene function and pathways of virion formation. Ph.D. dissertation, University of Mississippi Medical Center, Jackson, MS

Sample R, Bryan L, Long S, Majji S, Hoskins G, Sinning A, Olivier J, Chinchar VG (2007) Inhibition of iridovirus protein synthesis and virus replication by antisense morpholino oligonucleotides targeted to the major capsid protein, the $18 \mathrm{kDa}$ immediate-early protein, and a viral homolog of RNA polymerase II. Virology 358:311-320

Seet BT, Johnston JB, Brunetti CR, Barrett JW, Everett H, Cameron C, Sypula J, Nazarian SH, Lucas A, McFadden G (2003) Poxviruses and immune evasion. Annu Rev Immunol 21:377-423

Song W, Lin Q, Joshi SB, Lim TK, Hew CL (2006) Proteomic studies of the Singapore grouper iridovirus. Mol Cell Proteomics 5:256-264

Summerton JE (2007) Morpholino, siRNA, and S-DNA compared: impact of structure and mechanism of action on off-target effects and sequence specificity. Curr Top Med Chem 7:651-660

Summerton J, Weller D (1997) Morpholino antisense oligomers: design, preparation, and properties. Antisense Nucleic Acid Drug Dev 7:187-195

Sun W, Huang Y, Zhao Z, Gui J, Zhang Q (2006) Characterization of the Rana grylio virus 3betahydroxysteroid dehydrogenase and its novel role in suppressing virus-induced cytopathic effect. Biochem Biophys Res Commun 351:44-50 
Tan WG, Barkman TJ, Gregory Chinchar V, Essani K (2004) Comparative genomic analyses of frog virus 3, type species of the genus Ranavirus (family Iridoviridae). Virology 323:70-84

Tang X, Metzger D, Leeman S, Amar S (2006) LPS-induced TNF-alpha factor (LITAF)-deficient mice express reduced LPS-induced cytokine: evidence for LITAF-dependent LPS signaling pathways. Proc Natl Acad Sci U S A 103:13777-13782

Teng Y, Hou Z, Gong J, Liu H, Xie X, Zhang L, Chen X, Qin QW (2008) Whole-genome transcriptional profiles of a novel marine fish iridovirus, Singapore grouper iridovirus (SGIV) in virusinfected grouper spleen cell cultures and in orange-spotted grouper, Epinephulus coioides. Virology 377:39-48

Thorpe C, Hoober KL, Raje S, Glynn NM, Burnside J, Turi GK, Coppock DL (2002) Sulfhydryl oxidases: emerging catalysts of protein disulfide bond formation in eukaryotes. Arch Biochem Biophys 405:1-12

Tidona CA, Darai G (1997) The complete DNA sequence of lymphocystis disease virus. Virology 230:207-216

Tran BN, Chen L, Liu Y, Wu J, Velazquez-Campoy A, Sivaraman J, Hew CL (2011) Novel histone H3 binding protein ORF158L from the Singapore grouper iridovirus. J Virol 85:9159-9166

Tulman ER, Delhon GA, Ku BK, Rock DL (2009) African swine fever virus. Curr Top Microbiol Immunol 328:43-87

Tweedell K, Granoff A (1968) Viruses and renal carcinoma of Rana pipiens. V. Effect of frog virus 3 on developing frog embryos and larvae. J Natl Cancer Inst 40:407-410

Verrier ER, Langevin C, Benmansour A, Boudinot P (2011) Early antiviral response and virusinduced genes in fish. Dev Comp Immunol 35:1204-1214

Wan QJ, Gong J, Huang XH, Huang YH, Zhou S, Ou-Yang ZL, Cao JH, Ye LL, Qin QW (2010) Identification and characterization of a novel capsid protein encoded by Singapore grouper iridovirus ORF038L. Arch Virol 155:351-359

Wang F, Bi X, Chen LM, Hew C-L (2008a) ORF018R, a highly abundant virion protein from Singapore grouper iridovirus, is involved in serine/threonine phosphorylation and virion assembly. J Gen Virol 89:1169-1178

Wang Q, Luo Y, Xie J, Dong C, Weng S, Ai H, Lu L, Yang X, Yu X, He J (2008b) Identification of two novel membrane proteins from the Tiger frog virus (TFV). Virus Res 136:35-42

Wang Z-L, Xu X-P, He B-L, Weng S-P, Xiao J, Wang L, Lin T, Liu X, Wang Q, Yu X-Q, He J-G (2008c) ISKNV ORF48R functions as a new viral vascular endothelial growth factor. J Virol 82:4371-4383

Wang S, Huang X, Huang Y, Hao X, Xu H, Cai M, Wang H, Qin Q (2014) Entry of a novel marine DNA virus (Singapore grouper iridovirus, SGIV) into host cells occurs via clathrin-mediated endocytosis and macropinocytosis in a pH-dependent manner. J Virol 01744-14 88: $13047-13063$

Whitley DJS (2011) Determinations of ranavirus gene function using an antisense morpholinomediated approach. University of Mississippi Medical Center, Jackson, MS. Ph.D. dissertation

Whitley DS, Yu K, Sample RC, Sinning A, Henegar J, Norcross E, Chinchar VG (2010) Frog virus 3 ORF 53R, a putative myristoylated membrane protein, is essential for virus replication in vitro. Virology 405:448-456

Whitley DS, Sample RC, Sinning AR, Henegar J, Chinchar VG (2011) Antisense approaches for elucidating ranavirus gene function in an infected fish cell line. Dev Comp Immunol 35:937-948

Williams T (1996) The iridoviruses. Adv Virus Res 46:345-412

Williams T, Barbosa-Solomieu V, Chinchar VG (2005) A decade of advances in iridovirus research. Adv Virus Res 65:173-248

Willis DB, Granoff A (1978) Macromolecular synthesis in cells infected by frog virus 3. IX. Two temporal classes of early viral RNA. Virology 86:443-453

Willis DB, Granoff A (1980) Frog virus 3 DNA is heavily methylated at CpG sequences. Virology 107:250-257

Willis DB, Granoff A (1985) Transactivation of an immediate-early frog virus 3 promoter by a virion protein. J Virol 56:495-501 
Willis DB, Thompson JP (1986) The Iridovirus frog virus 3: a model for trans-acting proteins. Microbiol Sci 3:59-63

Willis DB, Goorha R, Granoff A (1984) DNA methyltransferase induced by frog virus 3. J Virol 49:86-91

Willis DB, Goorha R, Chinchar VG (1985) Macromolecular synthesis in cells infected by frog virus 3. Curr Top Microbiol Immunol 116:77-106

Willis DB, Essani K, Goorha R, Thompson JP, Granoff A (1990) Transcription of a methylated DNA virus, nucleic acid methylation. Alan R. Liss, Inc., New York, pp 139-151

Wilson WH, Van Etten JL, Allen MJ (2009) The Phycodnaviridae: the story of how tiny giants rule the world. Curr Top Microbiol Immunol 328:1-42

Xia L, Cao J, Huang X, Qin Q (2009) Characterization of Singapore grouper iridovirus (SGIV) ORF 086R, a putative homolog of ICP18 involved in cell growth control and virus replication. Arch. Virol. 154:1409-1416

Xia L, Liang H, Huang Y, Ou-Yang Z, Qin Q (2010) Identification and characterization of Singapore grouper iridovirus (SGIV) ORF162L, an immediate-early gene involved in cell growth control and viral replication. Virus Res 147:30-39

Xie J, Lu L, Deng M, Weng S, Zhu J, Wu Y, Gan L, Chan SM, He J (2005) Inhibition of reporter gene and Iridovirus-tiger frog virus in fish cell by RNA interference. Virology 338:43-52

Xu X, Weng S, Lin T, Tang J, Huang L, Wang J, Yu X, Lu L, Huang Z, He J (2010) VP23R of infectious spleen and kidney necrosis virus mediates formation of virus-mock basement membrane to provide attaching sites for lymphatic endothelial cells. J Virol 84:11866-11875

Yan X, Yu Z, Zhang P, Battisti AJ, Holdaway HA, Chipman PR, Bajaj C, Bergoin M, Rossmann MG, Baker TS (2009) The capsid proteins of a large, icosahedral dsDNA virus. J Mol Biol 385:1287-1299

Yan Y, Cui H, Jiang S, Huang Y, Huang X, Wei S, Xu W, Qin Q (2011) Identification of a novel marine fish virus, Singapore grouper iridovirus-encoded microRNAs expressed in grouper cells by Solexa sequencing. PLoS One 6:e19148

Yan Y, Cui H, Guo C, Li J, Huang X, Wei J, Qin Q (2013) An insulin-like growth factor homologue of Singapore grouper iridovirus modulates cell proliferation, apoptosis and enhances viral replication. J Gen Virol 94:2759-2770

Yan Y, Cui H, Guo C, Wei J, Huang Y, Li L, Qin Q (2014) Singapore grouper iridovirus-encoded semaphorin homolog (SGIV-sema) contributes to viral replication, cytoskeleton reorganization and inhibition of cellular immune responses. J Gen Virol 95:1144-1155

Zhang QY, Gui JF (2012) Atlas of aquatic viruses and viral diseases. Science Press, Beijing

Zhao Z, Ke F, Gui J, Zhang Q (2007) Characterization of an early gene encoding for dUTPase in Rana grylio virus. Virus Res 123:128-137

Zhao Z, Ke F, Huang YH, Zhao JG, Gui JF, Zhang QY (2008) Identification and characterization of a novel envelope protein in Rana grylio virus. J Gen Virol 89:1866-1872

Zhou S, Wan Q, Huang Y, Huang X, Cao J, Ye L, Lim TK, Lin Q, Qin Q (2011) Proteomic analysis of Singapore grouper iridovirus envelope proteins and characterization of a novel envelope protein VP088. Proteomics 11:2236-2248 